\title{
THE PILGRIMAGE OF DOROTHY RICHARDSON
}

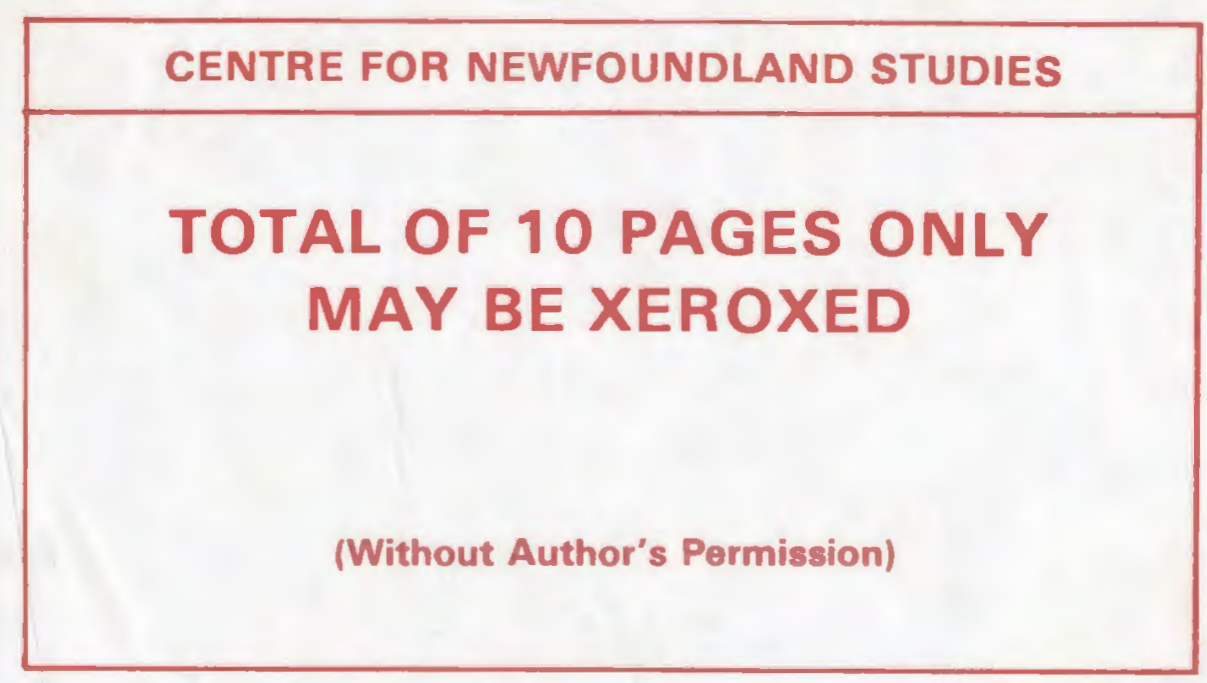

\section{TOTAL OF 10 PAGES ONLY MAY BE XEROXED}

(Without Author's Permission)

MARY W. RUSSELL 


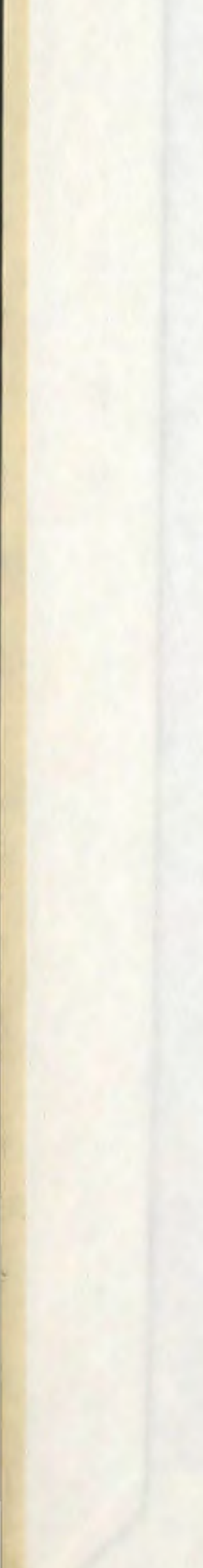




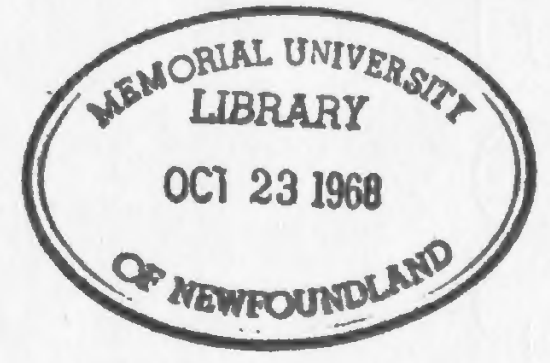


147042 
TIE PIIGRIMAGE ON DOROLIY RICIARDSON

(c) Mary Winifred Russell, 33.A., B.A. (Td.)

Submitted in partial fulfilment of the requirements for the degree of llaster of Arts lemorial University of liewfoundland, iviarch 30, 1968. 
Criticism of Pilgrimage has been limited by three preoccupations. inly critics were mainly concerned with the stream of consciousness technique or more generally with the problem of presenting egocentric experience. When this was exhausted, Pilgrimage was dismissed as the outpourings of an uninteresting mind. When it was found to lack the anticipated finish or shape of a novel, Eilgrimage was dismissed as a decidedly minor backwater in the novel of the twentieth century.

Pilgrimage appeared to arrive nowhere, its style was considered difficult and obscure, partly because the time lag between the appearance of early and late books was too long for the novel to maintain a sense of continuity, and partly because the critical reader did not know how to approach the novel.

Viewed as a whole, however, it is a book rich in life as lived by the late Victorians, and it is a witness to Dorothy Richardson's mystic outlook on life. But Dorothy Richardson's main concern was with art itself. As she began Pilirimage in protest against the novel as conceived and written by men, so she employed it as a means of criticizing society's attitude to life. More specifically Pilcrimage is a criticism, with all its connotations, of the literary world. Dorothy 
Richardson sends lifiriam forth upon a quest, not only in the mundane atmosphere of "current existence," but also in the more rarified air of literary endeavour. What liriam found and her reactions to her findings are the main core of Pilgrimage. Music, graphic art and literature are the motifs used to emphasize the main theme.

Dorothy Richardson, who set out to write Pilgrimage because she disagreed with the male approach to the novel, with strong masculine logic, consistently and unremittingly pursued her aim, taking over twenty thousand pages to prove her point. liodern readers are beginning to discover, consistently worked out, a presentation of a peculiar and cohesive way of living. The book thus has accuired added stature because of what it conveys about the typical member of a literate twentieth century society. 


\section{TAIBLE' OII CONTEITIS}

Chapter 1

Chapter 2

Chapter 3

Chapter 4

Chapter 5

Notes

Bibliography
The Lesser Ihreads

1

$\dot{4}$ Hasterly Copy of Many l'hings

20

Sound and Picture

46

Irrom Reader to Writer

69

The Marking-Off Place

129

137

145 
AIl quotations and references to Pilurimage are from the Dent edition of 1967.

Unless indicated thus [. . ], ellipses are those of the author quoted. 
CHAPTER ONE

IPHE LESSER MHREADS

- 1 -

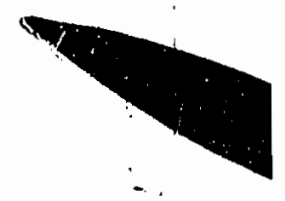


In attempting an analysis of Dorothy Richardson's Pilgrimage we are assuming a task which at the very outset poses a problem. Pilgrimage does not lend itself to the usual critical analysis of form, plot, characterization, for they do not present themselves as we have come to expect them in the conventional novel. Indeed Dorothy Richardson's reason for writing Pilgrimage, so clearly expressed in her foreword to the 1938 edition, should warn any critic that more than routine procedures would be required in assessing this work of art.

In her Foreword to Pilgrimage, Dorothy Richardson leaves her prospective readers in no doubt as to her opinion of the current novel. Having paid tribute to Balzac, 'Pather of Realism,' and 'his first English follower,' Arnold Bennett, both of whom she considers 'realists by nature and unawares,' Dorothy Richardson condemns the realist novels of their successors as being in the main, satire and protest, smacking strongly of biography and autobiography, she states her intention thus:

Since all these novelists happen to be men, the present writer, proposing at this moment to write a novel and looking round for a contemporary pattern, was faced with the choice between following one of [Balzac's] 


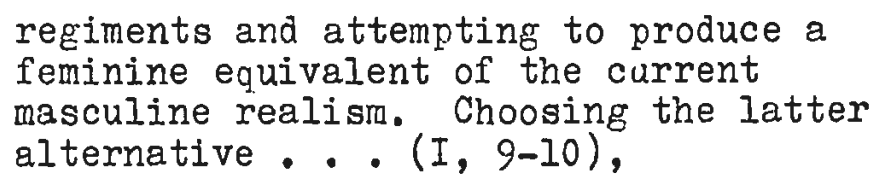

she goes her own way, producing the realistic novel with a difference.

Her chief quarrel is with the 'masculine' approach wherein the writer, absorbed in logical development of plot and character, frequently ignores, or forgets, the deeper emotional side of existence, the very 'life' of the book, Dorothy Richardson feels. Leon Edel in The Psychological Novel neatly sums this for us:

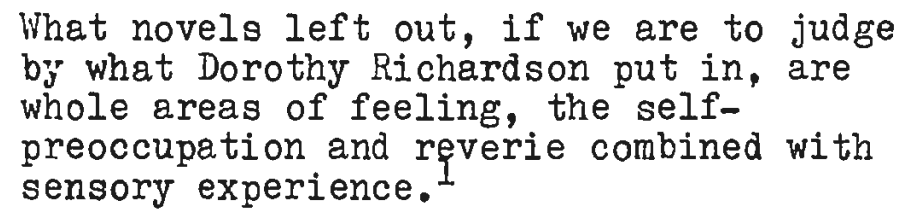

Dorothy Richardson has delivered to the world a book that is entirely different, one that presents life not only from the 'feminine' point of view but from that of one feminine consciousness, Miriam Henderson's: at the beginning of the novel an impressionable, inexperienced girl of seventeen, blossoming into early womanhood and gradually discarding the attitudes and reactions of the adolescent as she embarks into the unknown arena of 'the world.'

Dorothy Richardson was a rebel; her method grew out of her very intention to rebel. Her aim was to write a novel with a difference, but in Pilgrimage we have a polarity: 
Dorothy Richardson has swung to the other extreme. Plot and its logically contrived climax and suspense have been so de-emphasized that some critics have condemned Pilgrimage as being incoherent and not a novel in the accepted sense of that word, while the reader has been tied without hope of escape to a double feminine point of view as the author imposes her anti-masculine attitude upon the completely feminine mentality of her character, Miriam.

One does not expect the period novel, the picaresque novel, or the dramatic novel to fit identical molds, because each is characteristically unique. Nor. When one seeks to determine whether Pilgrimage is a novel, can one give a definitely negative answer if it fails to comply smoothly with the requirements of any one novel that has presented itself in the long chain of literary development. Though Pilgrimage does embody some of the characteristics of each. variation of the novel as it is examined individually, yet it is a work apart, resting on its distinctive qualities, another step or phase in the long history of novel writing. Pilgrimage is a novel that reflects, as did its predecessors, the interests and the new approach of its owm literary times. Again it is difficult to assess as one novel a literary work spanning the author's lifetime, especially when author and character, during those years, are going through a process of maturation at similar rates though at different 


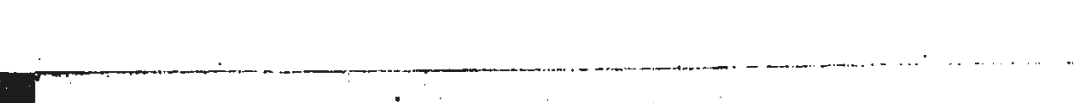

levels, the character at the end of the book having arrived at that point of maturity achieved by the author at the beginning of the book. Furthermore, life is not one logical sequence of happenings. We come and go, mingle and intermingle, forget and remember, rejoice and despair. Life is a matter of being not merely becoming; it can have no preconceived or prescribed end. And Dorothy Richardson chooses to deal with life. "The surprising thing," says Miriam Henderson, "is not that there is no curtain, but that there ever is anything on which to let a curtain down." Since Pilgrimage, as Dorothy Richardson confesses, was the direct outcome of a revolt against the 'conventional' form of the novel, so Pllgrimage, as we hope to prove, was a criticism of all aspects of what Michrel Shatov, a Russian student in the book, calls 'novelistic writiñ.' In Pilgrimage Dorothy Richardson wrestles with the problems of her craft, and if she has not emerged entirely successfully, as some have been prone to claim, she has won an acknowledged place among those who brought to the literary world a new awareness of the shortcomings and the potentialities of their craft.

Since the appearance in 1915 of the first 'chapter', Pointed lloofs, Pilgrimage has received a moderate share of criticism, contemporary and modern, some of it adverse, much of it significantly constructive, but all of it according Pilgrimage a unique place in literary history because of its 
importance in pioneering what May Sinclair, in 1918, much to Dorothy Richardson's chagrin, dubbed the 'stream-ofconsciousness' technique. There is no drama, no situation, no set scene. Nothing happens. It is just life going on and on. It is Hiriam's stream of consciousness going on and on. ${ }^{2}$

John C. Powys, life-long friend and self-appointed champion of Dorothy Richardson, regards Pilgrimage as 'a biography of a human soul.' Miriam, a symbol of human experience, is embarked on

$$
\begin{aligned}
& \text { a sort of Quest of the Holy Graal . . the } \\
& \text { divine object of the ecstatic contemplative } \\
& \text { life nothing less than the Beatific vision; } \\
& \text { and not merely for this alone; for she is } \\
& \text { looking for this as it manifests itself, in } \\
& \text { diffused glory, throughout the whole } \\
& \text { inflowing and outflowing tide of phenomena. }
\end{aligned}
$$

Had Powys known, his quest theme might have been further substantiated by the epic suggestion of twelve books in the completea Pilgrimage, although Gloria Glikin contends that this was not Dorothy Richardson's intention.

In his Introduction to the Dent edition of 1967, Walter Allen seems to regard this 'inflowing and out.:Lowing tide of phenomena,! what he calls 'current existence; the ultimate astonisher,' as the integrating theme of Dorothy Richardson's Pilgrimage.

To render current existence as reflected in the consciousness of her heroine, Miriam Henderson, was precisely the task ahe set herself $(I, 3)$. 
Pilgrimage, he affirms, is very much a novel of its time.

Earlier, in The English Novel, Walter Allen states equally as firmly that it is impossible in Pilgrimage to speak of structure or form at all:

It contains in the accepted sense no plot, no comedy, no tragedy, no love interest or catastrophe; there is only Miriam Henderson, living from day to day, experiencing, feeling, reacting to the stimulus of the outside world of people and things: life for Miriam is precigely 'an incessant shower of innumerable atoms', and reading, we live in an external present. $[.$.$] of$ Pilgrimage it might be said that if one robbed Miriam of her sensibility there would be no novel and no Miriam but also no world at all.4. .

At the end he is left wondering what is the significance of it all. Did Dorothy Richardson regard the world merely as fodder for her characters?

In his earlier assessment Walter Allen seems to have taken a superficial view of Pilgrimage and his deductions are reasonable at that level. One does not discover any plot or structure of pilgrimage at first glance. It seems to be merely an unassorted mass of memories and impressions as Miiriam lives from day to day. Leon Edel, in discussing the psychological novel, is fully aware of this.

There is no "story," no "plot." And above all, this kind of novel seemed to turn the reader into an author: it was he, ultimately, who put the story together, and he had to keep his wits about him to accumulate his data. 5

The psychological novel cannot be 'read' in the usual sense, 
it can only be re-read. And this precisely is what walter Allen must have done before writing his Introduction to the 1967 reprint. Only then did he discover that the accumulation of experience was being used with an almost masculine logic to portray the pilgrimage of an ardent, aspiring, intelligent young woman through the period from the $1890^{\prime} \mathrm{s}$ to the first World War.

To grasp its full significance, Pilgrimage must be read as a whole, Walter Allen points out. What appear to be blemishes in the earlier books will take on added meaning as the reader--and Miriam--progresses. Pilgrimage is a unique novel, the direct product of the age in which it was written, and it is the story of the development of a woman of that age. Allen notes, but does not emphasize, autobiographical evidence in Pilgrimage; he further suggests that Dorothy Richardson, an ardent feminist, may have used Pilgrimage as a literary expression of her "suffragettism." His first appraisal of Pilgrimage was a negative one, ending in a query; his second approach is more positive, and through it he f'inds the answers to his own earlier questioning.

Caesar Blake, 6 in his 1960 monograph, carries the quest theme further still. Using Evelyn Underhill's definition of mysticisn, "a quest for reality which in religious terms, promises the perfect consummation of the love of God," and the five stages in this quest for reality--self-awakening, purification, illumination, 'the dark night of the soul,' 
and the unitive state,--Blake shows how Miriam, at first subconsciously, then deliberately, set out on this course, although he feels that she fully attained the first three steps only.

Psychologically prone to feelings of transcendence, and yearning for a satisfying idea and experience of God; seeking a social and moral ideal which fulfills the individual and assures social organization; preferring the intuitive, synthesizing, comprehensive feminine consciousness, Miriam is a ready candidate for mysticism, Blake asserts. Though vaguely aware throughout the early books, and more strongly so in The Trap, of the pull of mysticism, it is not, Blake informs us, until her holiday in Switzerland, that she attains the first step of self-awakening. Against the majestic setting of Oberland she experiences an exhilarating feeling of eternity: a revelation of external splendour combined with a shining vision of a transcendental spiritual world.

The second stage, Purification, is reached in Dawn's Left Hand. Here, says Bloke, she proves herself capable of detachment or negation of divisive interests and desires, and of mortification or positive assertion of new interests and desires. Thirty-year old Miriam can now provoke the transcendental feelings at will. She realizes that the triple world of art, sex and religion must be rejected or purified 
of the mundane or the sensual. Seeking the spiritual in love, she severs ties with Michael and with Hypo; she leaves the world of her family, her work, her lover and "pushes on to some new way of being." At Dimple Hill she achieves Illumination, through which she experiences the full presence of God, seeing his "sly smile" in a brilliant light in the tree-tops. Through Contemplation she glimpses an illuminated vision of the world in the Quakers' way of life and casts off the old religion, while in attempting to write a novel that is not a confession but "alive all over" she finds reality in art. The triple tangle of art, sex, religion, no longer hamper Miriam in her mystic quest--or obscure her goal. The final Unitive State, obliteration of self, time, finitude may have been reached in March Moonlight. "While I write," says Miriam, "everything vanishes but what I contemplate. . . Contemplation is adventure into discovery; reality (IV, 657)."

In tracing the stages of development of Dorothy Richardson's life view implicit in the development of Miriam's consciousness, Blake has sought, and believes he has found, the underlying meaning of Pilgrimage in Niriam's impressions of and reactions to life. This provides a definite structural pattern to the novel, and furnishes a basis for analyzing Dorothy Richardson's technique. Though Pilgrimage has been regarded by some critics as an enigma of form and meaning, Blake, as a result of this analysis, credits Pilgrimage with possessing coherence and integrity as a novel. 
B.M. Maisel, 7 writing in 1939, also sees Pilgrimage a.s a mystic novel, drawn from a mysticism in Dorothy Richardson and manifested in the mysticism within Miriam that is most clearly revealed in Miriam's attraction to and adoption of the Quaker faith. Maisel fully uses Dorothy Richardson's monograph The Quaker Past and Present (1914), in developing this theme. The enlightened Quaker holds the view that truth cannot be found in outward things, direct inspiration is present in the lives of all men, and man must live always in that same light proceeding fresh and universal from directly within him, all of which may help to explain Miriam's search for that inner light, for "illumination."

Conditions necessary for self-realization, Dorothy Richardson continues in her monograph, are Solitude, Intuition, Action and Doctrine. Solitude practiced apart from the world of people leads to solitude that is awareness amongst people, but discipline for solitude is arduous and long, privacy and silence being first requisites, and room in which to savour the quality of life. Mental and physical silence are necessary to transcend the habits of sense. The Quaker is guided by intuition rather than intellect: from the inner light direct apprehension of reality follows the necessity of solitude. And Miriam's is an on-going search for that "inner light."

Gloria Glikin, ${ }^{8}$ however, has written a Doctoral thesis which dwells upon the autobiographical content of Pilgrimage, 
and it is Gloria Glikin, perhaps, more than any other, to whom we are indebted for her meticulous research into Dorothy Richardson's writings and papers, and her minutely detailed comparison of the author Dorothy with her creature Miriam. "The portrait of Dorothy Niller Richardson must take its lines from her sequence novel," she writes. Using her biographical sketch of Dorothy Richardson one can easily trace similarities between the person and milieu of Dorothy Richardson and those of Miriam Henderson. To what extent Dorothy Richardson meant Pilgrimage to be autobiographical is not important to this thesis. I shall merely indicate briefly the most outstanding resemblances, to emphasize the implication that Miriam is the voice and thought of Dorothy Richardson, an implication I shall reinforce by reference to comments by other critics and people who knew her.

Dorothy Miller Richardson was born May 17, 1873 to Charles and Mary Richardson at Abingdon, Berkshire. With her sisters Kate, Alice and Jessie, she lived at Albert Park until 1881 when financial difficulties necessitated a move to Worthing on the Channel Coast. When conditions improved, in 1883, they moved to a more luxurious home at Putney, a South-West suburb of London. In 1890, however, financial conditions worsened and, in order to be self-supporting, Dorothy Richardson, a little over seventeen, sought a teaching position in Hanover, her father escorting her there early in 1891, (as Miriam's father later would escort her). 
Dorothy returned six months later to find Jessie engaged, Alice a governess in an opulent Wiltshire home, while Kate remained at home to care for their ailing mother. In October 1891, Dorothy accepted a position in IIiss Ayre's School at Finnsbury Park, North London. Four years later she became a governess in an upper class family, a position she relinquished to care for her mentally ill mother, whose suicide shortly afterwards brought dark tragedy into her life. Dorothy then became assistant to J.H. Badcock, a Harley Street dentist, at a salary of 1 per week. She lived at Endsleigh Street in Bloomsbury near the British Museum, her friends being Benjamin Grad, a Russian Jew, prototype of Michael Shatov; her cousin Charles Daniels and his wife Florence, whose fictional counterparts were the Taylors; Amy Catherine Robbins and H.G. Wells-recreated as Alma and Hypo Wilson in Pilgrimage--at whose home she was introduced to the literary world. In 1905 she moved to Woburn Walk, near Flaxman Terrace, in the shadow of St. Pancreas Church, where W.B. Yeats was a neighbour. Miriam also came to know Yeats by sight when she lived at Flaxman's Court.

After ten years as dentist's assistant Dorothy was given a trip to Oberland by her employer, J.H. Badcock. She returned the following year to French-speaking Vaud. Shortly after this she resigned her position to devote full time to journalism, during 1906 and 1907 contributing essays and reviews to "Ye Crank" and "The Open Road." She spent some 
time at Hindnill $\mathrm{Hill}$, the direct source of her first imaginative writing, and the scene of a deep personal experience for her. In 1912 while staying at the home of J.D. Beresford, author and critic, she prepared to write a novel about what she knew, her own life. Soon she discovered that she could not continue talking about Miriam, Miriam must be permitted to speak for herself, so the Pilgrimage technique came into being.

Dorothy lived for some time at the Young Women's Bible Association Hostel, then moved to St. John's Wood, where she met the artist Alan Odle, whom she married in 1917. She continued to write 'middles' for the Saturday Review, as Miriam does in March Moonlight. In 1914 she wrote two Quaker works. She died June 17, 1957.

Dorothy Richardson transferred to Miriam, so Gloria Glikin tells us, the distinctive gifts and qualities she herself possessed: sturdy will and self-trained discipline, her ear for music, her hands to draw music from the piano, and her talent for mimicry and mimesis.

But Pilgrimage is more than a self-portrait, Glikin says; it gives more facts about Dorothy Richardson; it looks more deeply into her most secret thoughts than an autobiographical sketch would (III, 245). The last pages of Pilgrimage, where Miriam begins to write her novel, corroborate the evidence of autobiography. Dorothy Richardson began to write Pilgrimage in 1912, and from that moment she has been 
leading Miriam to write, to discover self-portrayal in an objective novel that will be subjective as well. Thus Miriam's pilgrimage becomes Dorothy Richardson's literary journey. Dorothy Richardson will live and relive her life, both halves at once, and Miriam's progress will be toward the act of writing through the same geographical route. Her own experience, all Dorothy Richardson could claim to know, becomes the source, the motivation, the substance of

\section{Pilgrimage.}

Joseph Prescott, 9 who edited "Data for a Spanish Publication", a brief biography of Dorothy Richardson, observes similarities between the author and her character in ancestry, childhood and education. The paternal forebears of both Dorothy Richardson and Miriam Henderson were Puritan tradesmen, while their maternal ancestors were West Country Yeoman landowners of the Iutheran faith. Dorothy Richardson's young life, as did Miriam's, brimmed with music, skating, boating and dancing. Dorothy's main concerns were her mother's health, free will, and Christianity, and for a while she was burdened with the good intentions of a governess. IIer educational bill of fare consisted of current events, Shakespeare, Browning, French, German, philosophy and music. Her main interests continued to be religion, science and philosophy. Miriam shared similar interests and concerns. Both Dorothy and Miriam disappointed their parents in being, not the long-anticipated son, but a third daughter in 
what would be a family of four daughters. Their respective fathers' misguided management of an inheritance in an overly-ambitious desire to win and maintain a position among the gentry precipitated ignominious ruin. Both followed the same route from dwelling to awelling borne by the tide of family fortunes and individual intent.

Miriam's career as a teacher in Germany whereby she hoped to become self-supporting, her position at Wordsworth House with the Misses Perne, her brief adventure as governess with the wealthy Corries, her longer engagement as dental assistant and her eventual emergence as a novelist echo her author's own experiences. The tragedy of the ill-health and suicide of Miriam's mother, Miriam's concern over religion and free will, her response to the literary and emotional appeal of Hypo Wilson (H.G. Wells), her interest in the socialist Lycurgans (Fabians), and her endorsement of woman's demand for political rights, are but a mirror-image of the life, the interests and the associates of Dorothy Miller Richardson.

Maisel ${ }^{10}$ also discovers marked similarity between Pilgrimage and Dorothy Richardson's own life: the metrical arrangement of Dorothy's and Miriam's names, six syllables ending phonetically alike with accents on the first and third syllables; childhood memories of a garden; ${ }^{11}$ similar careers as teachers and as dental assistants; their literary contributions to anarchist magazines; their interest in 
Jewish problems, their connections with Quakers and their concern with the art of translation. Miriam reflects the way Dorothy Richardson talks; Miriam speaks and Dorothy Richardson seems to interpret. Both were mystics.

On the other hand John C. Powys, ${ }^{12}$ one of Dorothy Richardson's most enthusiastic critics, regards her as a person rather unlike Miriam, although Miriam strongly resembles her creator in her keen ear for music and her gift of mimicry. He advises against seeking parallel identities in Pllgrimage; the book should be read, weighed and enjoyed on its own merit and Miriain accepted or rejected at her own worth, and not as an impersonation of her author. Joseph Warren Beach, whose book The Twentieth Century Novel (1932) is in biographical matters most likely derivative upon Powys' book, though he may be regarded as the more reliable literary judge of the two, also notes the resemblance between Dorothy Richardson and Miriam; but he cannot determine whether Dorothy Richardson is giving plain autobiography or has simply succeeded in identifying herself completely with her character Miriam Ilenderson. ${ }^{13}$

We also have Dorothy Richardson's own comments on the topic. In reporting an interview with seventy-seven year old Dorothy Richardson, Vincent Brome quotes her as saying "My novel was distinctly autobiographical. Ilypo was Wells, Miriam in part myself and Alma, Mrs. Wells. "14 His reference to two small armchairs which were placed, not opposite, but 
in line with one another, bespeaking a powerful prejudice against sitting opposite to people, his mention of masculine handwriting gives one cause to query, Dorothy or Miriam? Tor these characteristics were applicable to them both, as we learn from Miss Glikin.

H.G. Wells, ${ }^{15}$ with whom Dorothy Richardson maintained a close relationship until his death, in his autobiography (1934) referred to Dorothy Richardson as having a very distinctive literary gift, possessing acute intensity of expression and an astonishingly vivid memory. Pilgrimage was a very curious essay in autobiography, he said, and in one of the books, The Tunnel, she has described the Wells' Park Life with astonishing accuracy. He figured as Hypo in that description, and Jane as Alma.

Harvey Eagleson, ${ }^{16}$ writing in 1934, considers Miriam a possible portrait of Dorothy Richardson. She may be an objective creation, but he thinks it highly unlikely; he knows of no objective creation so carefully analyzed and presented in such detail; in fact the entire novel smacks of autobiography. Dorothy Richardson's Obituary in the London Times, 1957, in referring to Pointed lioofs, re-affirms this conviction.

A broader concept of Miriam and of Pilgrimage is presented in 1959 by Horace Gregory. He envisages ifiriam as Dorothy Richardson's eye view of the world, a seeing eye awake upon a long journey; a.t other times she is an 
'atmosphere' through which her friends go walking. She is the author's source of opinions and reflected commentaries. She is the eye, the voice, the presence of a human personality, in short the chorus in Dorothy Richardson's Comedie Humaine; for Pilgrimage, as Gregory sees it, is a true humanistic comedy. From the moment Miriam sets out on her pilgrimage she is alert to the follies and weaknesses of human society.

Miriam's moral, social, political views, Miriam's observations . . reach their conclusions by associating sham male superiority with the creeds of middle-class compromises, subterfuges, economic prejudices and complacencies. 1 ?

Miriam appears to Gregory as a Bergsonian Comic Spirit who will reveal, ridicule and perhaps remove the ills of the society in which she lived and moved and sought her inner being. 
CHAPIER TWO

A MASTPPLY COPY OF MANY THINGS

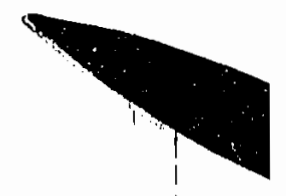


The modern novel, it has been said, ${ }^{1}$ impinges more and more upon the social side of man's existence--a debatable point, not to be challenged here. True it is, however, that in Pilgrimage we are given a vivid portrayal of a class--a class with whom Miriam mingles as she matures from a. young girl of seventeen to a woman of forty with a much broader outlook on life. We see this class from the point of view of Miriam as an emancipated young woman becoming acclimatized to the competitive atmosphere of the work-a-day world, or a budding writer learning her way among the startling beliefs of modern literary groups; as a young lady holidaying among the much-travelled citizens of the world; as an intelligent, enthusiastic member of a socialist society; and as a sensitive human being seeking to identify and establish her own inner self.

Miriam is a citizen of a Puritan world, a Bloomsbury world, a Victorian world. Representative of. Puritan society are the Blooms, Miriam's grandparents, and the pupils of a North Iondon school; closer at hand are her Bloomsbury associates united by their love of books, of music, of philosophy--of their fellow men; while enveloping these is the broader Victorian society, whose doubts and fears and 
conflicts are brought to light as Miriam strives to reconcile Iife and her conception of God. Miriam seeks a God compatible to the feminine consciousness, not a harsh, all-judging God, designed and interpreted by the masculine mind, but a loving, understanding Presence attained and comprehended only through contemplation.

Hore narrowly still we are given a portrayal of a woman of the late- and post-Victorian period, as Dorothy Richardson seeks to incorporate into this one character the restlessness and tranquility, the hopelessness and faith, the courage and despair, the ever-reaching outward and onward to broader horizons on a physical and mental plane, so indicative of this period. For this is an age of great discoveries-an amazing and a daring age in which to live, and the middle-class living in this age is a leisurly class, though progress is forcing it to speed up, as Dorothy Richardson tries to indicate in her portraiture of liiriam.

This is an era when the brougham, the victoria, the hansom are elegant means of transportation, and the horse-drawn bus still dashes along the level stretches of country and slows to climb a hill, but that era is changing: the train rolling 'slowly in behind its beloved black dumpy high-shouldered engine with its unshrieking mushroom bell-whistle' is coming into its own. Miriam travels with a Pilgrim basket, a Gladstone bag or a Saratoga trunk, her choice of luggage determined by the length of her journey and 
the duration of her stay.

Cycling is becoming the vogue for adventuresome young ladies, but Miriam's cycling holiday is a startling conquest. Miriam's hired cycle, 30 bob per month, its nuts tightened, its wobbly head repaired by Gerald, its Brooks saddle; its Lucas Baby bell, its adjustable spanner, is ready to take her venturing as far as Marlborough--and a flat tire.

This, too, is an age of boating and tennis and golf, and skating and tobogganing; the new age of telephones and telegrams and cold bright electricity replacing warm flickering candles and the cozy lamp, the age of the cinema where audible conversation replaces the printed words of the 'silents.' It is an era of visits to the Royal Institutions and the British Museum, of evenings viewing coloured photographs; it is the era of the comet.

Thts is the era of emancipation when only the daring woman publicly joins her male companion in a cigarette. Miriam is a woman of her time, having smoked her first cigarette when she was seventeen; and Miriam, who has joined Mr. Corrie and his companions in a game of billiards, joins them also in a smoke. "It's a pleasure to see you smoke," says Mr. Corrie "you're the first woman I've seen smoke con amore." Miriam discharges a double stream of smoke violently through her nostrils, breaking out at last in public defiance of the free-masonry of women. It is the era of the suffragette. 


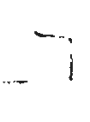

24

Borne along by means of Miriam's consciousness, we attend a Victorian wedding with all the flurry of preparations and last-minute worry over bouquets and bridesmaids' dresses, with its sacred church ceremony and gay reception afterwards, until suddenly comes the tender moment of farewells and the happy couples drive away in a shower of rice and good wishes. There follows the sober chore of attending to gifts and sending out cake in little boxes. Dorothy liichardson omits no detail. In her view of life it is the minutiae and not just the major events that truly make up existence.

We spend a whole evening amid the noise and confusion of the Crystal Palace, with its fireworks and its toboggan, the latter an exhilarating adventure (I, 323-328). There is a circus, too, and we watch it in the guise of Miriam. We join Miriam and Mrs. Corrie on a hat-shopping spree, highly unproductive for all concerned. We attend evening entertainments where we enjoy the music of the old masters, memorles of which are captured and revived through phonograph recordings. We peep inside hospitals, visit charity wards, explore new fields of surgery and psychiatric care, and trace the evolution of dontology through the efforts of Mr. Hancock; while the microscope and the telescope open up whole new worlds hitherto beyond the range of human eye (IV, 405-407).

We accompany Miriam to lectures where Darwin is the most controversial topic of discussion. Iater, in conversation with her friends, Miriam gives her interpretation of his 


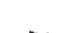

theory. We are not descended from monkeys at all, she declares. It's not natural. The great thing Darwin did was to point out the power of environments in evolving the different species through selection. And she offends them all.

Miriam is constantly directing a sweeping glance at the audience, their dedication or assumed interest, their clothing, their lives reflected in their wise or worn or cynical faces; their inner Iives written in the way they walk or assemble their outdoor attire. We cannot but note the "massed intellectuality of McTaggart's audience."

Miriam's budding awareness of social injustice is given added stimulus when Hypo Hilson, an active member of the Iycurgans (Dorothy Richardson's veiled presentation of the Fabians), inveigles her into the intricacies of that society. Her response to the urgent need of the masses is immediate and generous as she religiously attends meetings, folds circulars, canvasses on behalf of the society and once, in a fervour of loyalty to the cause, refuses to let a bout of fever keep her from casting her vote. So incensed does she become on one occasion by some unknown clerk's problem, that, in a spirit of identification with the victim of an over-commercialized society, she criticizes her employer, Mr. Hancock, with unrestrained bluntness, thus precipitating her own dismissal, which, she, Miriam-like, refuses to accept. 
She is Ereatly disturbed by the lack of practical assistance coming from all soclalists; they mouth high-flown but empty phrases. If a man cannot determine light within himself, Miriam wants to know, how can he determine his relations with other men? Miriam is critical of all society, not only of the callous treatment accorded the unfortunate and the downtrodden, but of the empty, vapid lives of so many accepted members of soclety pretending to happiness they do not feel. Drawing-rooms are filled with ladies acting like puppets in response to expectations of male assumed superiority. But Dorothy Richardson feels there is an inner happiness in everyone everywhere awaiting the chance to come out.

Mirlam finally sees the Lycurgans as they really are. Their meetings have been empty shows. Disillusioned, Miriam and Hypo Wilson resign from the Lycurgans, retiring from futility and blindness. The Iycurgans, Miriam realizes, are standing still marking time, or marching in increasing batallions in the wrong direction. Miriam's concluding thoughts condemn socialism as an empty, dry desert, or at most, an appealing mirage.

II

The character through whom Dorothy Richardson reveals the world of the emancipated working girl of the late Victorian period seems always to be hungry; this provides an 
opportunity for a discussion of food, or for a visit to such restaurants as a girl in Miriam's social stratum might reasonably be expected to frequent. One can almost trace Miriam's growing sophistication through her selection of eating places. More significant, perhaps, these would be places frequented by Dorothy Richardson and her literary friends in her day.

Intensely disliking to do her own cooking, Miriam eats regularly at an A.B.C. with its buns and boiled eggs and tea. The food is honest; the surroundings are not showy, rather they are blissfully dowdy. "I have come to the conclusion I like dowdiness," thinks Miriam. "I'm not smart." There is an honesty to dowdiness, she feels, smartness often implies artificiality.

Representative of the foreign element in London is the restaurant of the Donizetti Brothers which an extremely hungry Miriam happens upon alone one midnight. She feels that inside those frightful frosted doors there is a home, a bit of her own London home (II, 360). But Miriam's roommate, Miss Holland, takes less kindly to the Italian-Swiss eating place. "Just this once," she says, though the place is clean and pleasant. To Hypo Miriam says, "Come and have coffee at my Donizetti's," wishing to show off her Donizetti, who always escorts Miriam to a table and to the door in a most courtly fashion, and never talks; except to give orders down the lift in Italian. 
Michael Shatov (who lacks this virtue in himself) fails to recognize that Donizetti is paying a tribute to womanhood and insults Donizetti by demanding a bill for a postage stamp given to Miriam; Donizetti runs him though with a look. Miriam is nourished by the courtliness, the kindliness, the understanding she finds at Donizetti's, attributes her friends do not recognize. Miriam tests her friends at Donizetti's and finds them wanting.

One of her fellow boarders, Mendizabal, takes Miriam to Roscino's ${ }^{2}$ where Miriam moves into a man's world; surprisingly, something within her responds to the masculine café atmosphere. Miriam feels like a man herself, sophisticated, cosmopolitan, almost blasé, looking at women from a man's point of view. While in the German atmosphere of Michael Shatov's "Dumme August" ${ }^{3}$ she moves one step further away from the preconceived image of woman, and drinks her beer like a man. Strangely, Michael does not consider it either shocking or vulgar. The Jew in Michael sees woman merely as a necessary factor in the continuity of the Race.

More in keeping with the background of the well-nurtured young lady is the Club where women entertain their friends, patronized on special occasions by Miriam's rooming-mate Miss Holland. Its quiet dignity, muted conversation, good china, soft firelight give a completely feminine picture, but it is overdone. Iights come on almost theatrically as tea is brought in. Miriam cannot find contentment in its 
overly-decorous atmosphere. The rebel in her struggles against this contrived image of refinement and she wants to say something outrageous, loud enough to startle the smug, conforming clientèle.

And something is sady amiss with the elegant restaurant where Miriam dines with Hypo and Alna after her return from Oberland. Hypo carefully orders from the French menu, but the lark pie brings sudden tears to Miriam's eyes so Hypo sends it back. The pie to Miriam typifies what is wrong with the attitude of all dining tnere,--seeking the exotic at such a cost to the happy innocent singing bird. They fail to hear the lark's song. Blind to the wonders of nature, they misuse her gifts to appease an avid appetite for entertainment, like the Roman of old seeking excitement at the cost of human life. What am I doing here? Miriam wonders. When Hypo declares that he and Alma plan to travel, Miriam responds, "There's more space within than without." The unexplored depths within a person offer a greater challenge than the far-away places of the globe. But Hypo and his ilk are content to live on the surface of things. There is one other--the shoddy restaurant with its "shame-faced half-lit room," and its "sheeny shame-faced armchair," the setting for a rendezvous between Miriam and Hypo--the final breaking down of moral barriers. The setting, Miriam feels, is a reflection of the sordid nature of the meeting, and a commentary on all those who arrange such meetings. 
The eating places that Miriam visits offer a contrast in their attitude toward woman. Not only do they reveal the many sides of Miriam's personality as she responds to these environments, but they show us the place accorded woman by the societies which these restaurants represent. We are given the man's view and the women's view of women. The Donizetti world treats Miriam with old-world courtliness, anticipating no sham response--Donizetti does not talk. Roscino's male café society meets women on equal terms. Vichael's ethnic group has no pedestal for woman, while the Club overemphasizes her femininity.. The restaurants Miriam visits with Hypo are indicative of two aspects of human society: a perverted sense of entertainment, and lust. The clientèle of the smart restaurant, like the Romans of old, derive pleasure at the expense of innocent blood. The lark is symbolic of the gladiator dying to entertain the patrician Romans. The patrons of the shame-faced restaurant indulge only in the sensual. Hypo, Miriam realizes, can truly love no one; he is, as she tells Amabel, merely a collector of virginities。

Private meals also have their significances. At Waldstrasse, the homely nourishing fare, milk and white rolls, is reinforced, on an occasional outing, with "thick-looking chocolate, supporting a little hillock of solid cream accompanied by an éclair or a tartlet," the latter being a test of one's restraint--a test that the seventeen-year old 
Miriam fails. At Waldstrasse one must maintain a healthy balance between wholesome plain nourishment and a too-rich diet.

Benefits do not come easily at Wordsworth House. The thick bread and butter must be well-chewed, though hurting tender teeth, to obtain the full flavour; the diet offers nothing really sweet and nice. There is satisfaction to be had in honest work, Wordsworth House seems to say, but there will be few luxuries.

The exquisite meals of the Corries', perfectly prepared, perfectly served, appeal to the senses of taste, smell and sight. The wealthy Corries' seek the most exquisite for themselves, but for the governess the unappealing, the unappetizing will do. The meal served Mrs. Corrie and Miriam, the night Miriam arrives, is too lavish for two people, almost a feminine version of a Jonsonian feast for Celia. ${ }^{4}$

The supper at Hypo's lacks life. Gay, cold, bright, pretty, it epitomizes the life of the Wilsons, a state of becoming, never being, never actually living, merely making gestures. It is a feast of death. Alna looks scornfully at Mirlam, who is seeking sustenance in large, plain biscuits and an apple.

It is strangely significant that Miriam is always hungry. The 'food' in each of these surroundings is insufficient to satisfy an inner craving. iler inner hunger is never fully appeased, so firiam moves from one locality to another. 
At the Quaker Roscorlas Miriam eventually finds food for both body and soul. There food has vital, spiritual goodness, a satisfying, sacramental quality; even in a potato grown upon the land some special virtue resides.

The food they serve may be regarded as indicative of the branches of society known to Miriam. The Germans believe in moderation, in a careful balance between the plain and fancy things of life. Industrial North London offers no easy road to accomplishment,--rather hard work, no 'sweets' included. The rich demand perfection for themselves disregarding the tastes and needs of others. But the Quakers, knowing the answer to their soul's needs, find it easy to provide nourishment for the body.

\section{III}

Houses, too, serve to identify a class. The private homes that welcome Miriam as a relation or a guest, the shoddy rooms in which she lives, the homes of Miriam's childhood, so vividly recalled, with their bee-busy gardens, trees, flowers, servants, music and books, the more modest residences after her father's financial fall, as well as the small cottages of her sisters, all reveal some feature peculiar to those who own them.

The houses in Dorothy Richardson's Pilgrimage can be examined from three angles: a pictorial description of each, a study of the class of the occupant, or a revelation of Miriam's unsuccessful (or successful) search for identity. 
Dorothy Richardson's graphic description of the Brooms' house with its 'lacquered knocker against a glazed and leaded door', as Miriam first glimpses it, is strongly reminiscent of a Victorian painting, each room one of a matching set: highly polished, solid mahogany furniture, Iimoges china, solid silver tea service, fine heavily-edged linen table cover; while the heavy, carven, age-long dreaming faces of the three women can well be a companion picture to the set ( $I, 289-290)$.

The Brooms particularly like to 'march with the times,' but only because within all times, however new, they have found what already they possess, over which time has no power-an unassailable serenity of being. Small wonder that Miriam keeps coming back to this source for renewal of spirit (IV, 136).

To step from the rather gloomy Puritan Brooms', covering their furniture at night with dust sheets, to the gay brightly-lit Corries' is a dazzling undertaking. At the Corries' spring is heralded by a change to frilled bed linen, lace-edged towels and flowered bed-spreads. People with money can make spring come as soon as the days lengthen, Miriam reflects. Their West End friend, Mrs. Kronen, provides a striking portrait in her mauve and white apartment, reclining on a mauve and white settee in a pale mauve tea gown, while on a large low table sits a frail mauve tea service ( $I, 412$ ). 
The artistic beauty of Newlands appeals to Miriam:

At Newlands the people might be dead, the women in bright hard deaths of cold, cruel deceitfulness, the men tiny insects of selfishness, but there were things that made up for everything, full and satisfying ( $I, 468)$.

But these things do not completely satisfy. There is more to life than material things, beautiful though they may be, Niriam discovers; there is that other something beckoning, a brightness that lures her ever cnward. Failing to find complete fulfilment at Newlands, Firiam moves on, thinking she may find it at Mirs. Bailey's to whom she is indebted for so much.

Mrs. Bailey's house, with its echoes of decadent grandeur, is of a large brown dinginess, but the welcome of the house falls upon her when she enters. Coming to Mirs. Bailey's is like dropping everything and walking backwards to something you know is there, Miriam thinks. Miriam is back where she was before she tried to do things like other people. The marble table-top may be grimy, the lace curtains smoke-grimed, and Miriam's room smelling drily of dust, but an air of past glory clings to the house, an atmosphere of understanding and trust and of life being lived.

In contrast to this is Plaxman's Court, where Miriam joins Miss Holland in a rooming experiment. At Flaxman's the air is dense with shut-in odours, dried brow by stale pipe smoke, a smell of long-lying Iondon dust; a blistered door. whose knocker, a blurred weather-worn iron face, gazes 
sadly downwards. On entering the little by-street for the first time liiriam has a sense of arriving nowhere (III, 400). There is nothing at Flaxman's to appeal to Miriam's aesthetic soul, the only suggestion of the finer arts being an alabaster finger given Miriam by the sculptor, Mr. Perrance, whose love of the beautiful is being slowly strangled by the horrors of his surroundings. Flaxman's Court reflects the anguish of life endured by the downtrodden masses. Miriam leaves Flaxman's to the echoes of Mrs. Perrance "weeping in despair, wi thout fear," and returns to Mrs. Bailey's.

When she visits Alma Miriam is conscious of a strangeness, a freshness and a coldness:

It was the strange shock of the bedroom, the strange new thing springing out of it,... the clear soft bright tones, the bright white light streaming through the clear muslin, the freshness of the walls ... the little cold change in the room after the books, strange fresh bindings and fascinating odd shapes and sizes, gave out theix names . . (II, 110 ).

The curiously wrought copper candlestick and the high-backed chairs to Miriam were gestures emphasizing a way of living designed and shaped by the Wilsons. In contrast to such pretensions, at the Roscorla's, a Philistine room is furnished without deference to shape and colour, a simple, unaffected room, self-sufficient as its owner.

Just as the meals selected and served by Miriam's friends and employers reveal the level of society to which they belong, so do the furnishings of their houses serve to ratify these findings. 
The Brooms are typical of one element of Victorian society, Puritan in outlook, refusing to accept the imitation or the shoddy. Their houses gleam with good furniture, warm firelight, sparkling linen. Theirs is the well-worn, the well-polished. The Corries can be identified with the luxury-loving class who surround themselves with beautiful, costly material things and believe they are living life to the full, while some vital part of their being slowly perishes. Mrs. Bailey's house typifies warm, kindly, shabby respectability that attracts to itself people of divers needs and outlooks desirous of sharing a little of the warmth, the kindliness and the respectability. The Wilsons' home is the centre of those who, like the candlestick and the nigh-backed chairs, make gestures and think they are living, bright and fresh and strong in their view--but cold. Finally, The roscorla dwelling speaks of the simplicity, the faith, the self-dependence within, its furnishings tangible evidence of the Quaker sect to which the owners belong.

\section{IV}

In his discussion of the novel E.M. Maisel, in 1939, notes several respects in which the mystic novel differs from the traditional novel, and Pilgrimage seems to possess these attributes. The conventional novel can be identified by its sequence of curtain, action, climax, denouement, curtain; but what is neglected in such a novel, as liirian herself sugrests, is the marvel of there being anything, at all for a curtain to 
rise on; the fundamental story, man's experience of reality, is always left out. The mystic novel, on the other hand, has no real beginning and no real ending; it begins and ends at any convenient point. In keeping with this, Pilgrimage, as Maisel points out, offers no final deposition of affairs, merely a marking off place. When Miriam having said good bye to her three worlds of family, erotic love and work, recognizes her place in the Quaker community (Dimple Hill), this is not the end of the novel, Maisel says, but a first stopping place in the pilgrimage of a mystic, and perhaps the only marking off place in a mystic novel.

For the mystic, experience of things is important, and Dorothy Richardson seems to be fully aware of this as she shows us Miriam's deep involvement with food, soap, 5 rooms, walls, carpets, lamps, trees, gardens--the environment. It is only the sum total of experienced actuality, llaisel believes, that affords any plot to the mystic novel. But Dorothy Richardson uses the things of life not only as the experienced reality of the mystic, but as a comment on the society in which Miriam lives. I have dealt at some length with Dorothy Richardson's comments on this society because it forms one interesting aspect of Pilgrimage, and to approach Pilgrimage as a rendering of a criticism of society may be the most satisfactory interpretation to date. I have also given in an earlier chapter the views of other critics. The novel itself would not be complete without the aspects they have 
chosen to discuss. I consider them important though minor threads of this lengthy work of art. There are, however, other aspects to be examined, among them Miriam's mystic quest which I hope to deal with in this chapter, and, for later discussion, Dorothy Richardson's use of the arts in presenting her interpretation of life.

Despite this involvement with things of life, the mystic cannot find Truth in outward things; he must live in a light proceeding from within himself. This may very well explain Miriam's search for inner light and her successful illuminations. After her transcendent experience at Wordsworth House, she wonders if it will come again, if it will get stronger all the time. Perhaps it will go on getting stronger till she dies. And Miriam does seem to be able to bring on those moments of illumination, until finally at Dimple lijll she reaches that ecstatic moment: "I have seen the smile of God (IV, 420)."

No one particular event seems to bring on the inner illumination, but we are given some: music, a bright view, skiing at Oberland, a kiss. Emma Bergman's piano playing works a mystic response. Again, Miriam slides to a "featureless freedom" during Clara's piano solo, seeing a wonderful light as she feels herself going forward and forward through space. After the thunderstorm Miriam is carried down into the heart of tranquility, "drinking as if at a source." Her favourite dream brings a sensation of floating through 
clouds and above tree-tops and roofs. Happiness expresses itself physically in a tingling from head to foot, a faint buzzing at the lips and at the tip of each finger.

During a moment of utter dejection at lordsworth House, she suddenly experiences while walking upstairs a pronounced mystic translation:

She became aware of a curious buoyancy arising within her, [. . .] for a second, life seemed to cease in her and the staircase to be swept from under her feet. . . 'I'm alive.' . . It was as if something had struck her, struck right through her impaleable body, sweeping it away, leaving her there shouting silently without it. I'm alive.... I'm alive (I, 245).

She tries once or twice deliberately to bring back the moment. What is the use of being like it, if it doesn't last, she protests.

Weeks later, at home listening to music, Miriam finds herself growing larger and stronger and easier until everything is dissolved, past, future, and present, and she is nothing but an ear. All the senses have been sublimated to that of hearing. Miriam seems to soar, oblivious of the physical and the immediate, her entire being fused with the music. Miriam's susceptivity to mystic enlightenment seems to have been there since childhood. At Brighton Beach, as a child of six, she experienced a "strange sense of joy," and younger still, toddling in the garden at home, she knew similar wonder and joy.

Now at Newlands among spring flowers and laughter, Miriam experienses frequent illuminations. Music, when Mrs. 
Kronen sings, brings a blaze of light and a vision of garden upon garden; while an unexpected kindness from Mr. Corrie causes a glow of radiance to surround her, outlined a.s though by a flashing blade. Miriam's illuminations are associated with a brilliant light and a heightening of some sense, that of eye or ear, and she sees things with vivid perception or hears with startling clarity; the illuminations are frequently accompanied by a vision of a little garden, ${ }^{6}$ and a sensation of floating. When Miriam first sees colored photographs, their intense rich colour heightening and brightening as they are flashed on a screen, she thinks that they, more than anything else, best express how she feels during those moments of transcendence.

Dorothy Richardson permits the reader to share Miriam's feeling at the wonder of Being when, discussing Grace's disappointing love story, she becomes suddenly aware of her own fresh flowing life, with its unchanging reality:

Life sang and danced around within her; shreds of song; the sense of the singing of the wind; clear bright light streaming through large houses, quivering on walls and staimways and across wide rooms. Along clear avenues of light radiating from the future, pouring from behind her into the inner channels of her eyes and ears, come unknown forms moving in a brilliance, casting a brilliance across the visible past, warming its shadows, bathing its bright levels in sparkling gold. Her free hands lifted themselves until only the tips of her fingers rested on her knees and her hair strove from its roots as if the whole length would stand and wave upright (II, 318).

Iven a lecture by the revolutionaries brings that "white 
radiance" making the surrounding light glow with greater intensity (III, 237), while at Oberland she is continually conscious of a feeling of "eternity."

Iife is eternal, she thinks, because joy is. Miriam's response to Michael's kiss, his gentle tremulous salutation finds expression in a blaze of light (III, 201).

But Miriam's inner radiance is a solitary experience, not to be transmitted to others. During Hypo's love-making her spirit escapes on some solitary journey:

Whose end came in a light that seemed the pale light of dawn. She was up at the high glimmering window, saw clearly its painted woodwork and the small blemishes upon the pane against which she pressed; through which, had it been open, she felt she could have escaped into the light that had called her thither (IV, 257).

This was a truly mystic experience, wherein she seems to have gone beyond the bounds of space; to have floated in its outer vastness.

Spring calls her, too. is she watches the clear sky radiant with joy, she deliberately invokes a transcendental experience, swinging clear of earth to hang suspended in the sky, drawing unto herself the joy that is everywhere up there; conscious of a crystalline vibration that seems to say, "Yes, this is reality (IV, 279)."

The active, involved life led by the maturer Miriam provides opportunity for less frequent illuminations as her interest in books and writing and people encroach more and 
more upon her precious moments of solitude, but those

'experiences,' though rare, are deeper, more meaningful and of longer duration.

Miriam's inner exaltation frequently is accompanied by or blended with an outer glow, and it is a.t Dimple Hill that this outer radiance suddenly holds for Miriam ultimate significance. Meeting unexpectedly a familiar quotation of Emerson's--a favourite author at this time--and bappening to glance up in astonishment, she discovers, upon the unper foliage of a group of trees, a patch of bright colour in a golden light, filling her with rapture at the sight. Suddenly she recognizes it as a direct sign from God. "At last I know! I have seen the smile of God. Sly smile (IV, 420)."

This is but the beginning of a wondrous mystic experience to be shared with her Quaker friends. But who is she, that she should expect to find herself all at once in the presence of God? Miriam asks as she tries unsuccessfully to reach the Quaker's depth of contemplation. She tries to force her thoughts down and down through a series of circles, each wider than the last, breathing deeply to bring on the contemplative state, but the immediate scene caught by her open eyes and the sounds of life outside pull her back (IV, 498). Then closing her eyes she finds herself journeying to some unlocated meadow, rain-drenched, and so near that sile can perceive as if she were a tiny animal in their midst, a forest of grass blades, the ribs, and filaments of each blade 
clearly visible. Then suddenly she is above the field, looking down upon an open stretch of country, perceiving here and there remembered spots of beauty (IV, 500).

Miriam's lone journeying has brought her at last to this. Now she can share the glad radiance of the Roscorla Quakers. No longer solitary, she feels that from herself some of this glad radiance must be flowing too, proving her no longer an outsider but one qualified by kindred experience for membership in the small company of believers (IV, 498).

In every individual, Dorothy Richardson believes, an inner radiant being waits to be sought and awakened if one but knew and tried. For Dorothy Richardson's Miriam it is the only reality to life, all other experience is but superficial and secondary. That inner self to Miriam is "an endless garden," "that brightness," "her untouched self, free unseen strong," the "inner twilight of her being," that other life that hitherto she could realize only when alone. Miriam's chief quarrel with men and with the women who react as the masculine ego dictates is just this: they leave unprobed those innermost depths wherein slumber the selves God meant them to be.

Miriam seeks not only her own inner self but the secret hidden being in others. It is finding the same world in another that moves one to one's roots, that makes life bearable, she believes. This is the essence of her final rejection of Hypo Hilson. Hypo moves horizontally toward 
some end he hopes to achieve; Miriam plunges vertically into the deepest recesses of innermost being. Miriam sees Ilypo as two people, a man achieving and a man seemingly uncreated.

For so dismally, in every one, he saw only what they were becoming or might become, and of the essential individual knew, and wanted to know, nothing at all (IV, 220).

As Hypo sees in others only what they are outwardly achieving and ignores the intrinsic side of their development, so he regards his own accomplishments, concerned only with visible, tangible goals, while the Hypo that could be lies undiscovered in his inmost depths, unawakened, uncreated. In his intimate association with Miriam he is concerned only with superficial pleasures of the moment, not perceiving that the real Miriam is walting to be discovered.

There was a woman, not this thinking self who talks with men in their own language, but one whose words could be spoken only from the heart's knowledge, waiting to be born in her (IV, 230).

But Hypo is incapable of homage and without it "INiriam can not fully come to birth for him (IV, 230)." Hypo does not even realize that he has failed to arouse IIiriam to complete physical and spiritual response. Hypo's masculine world moves too fast to admit of intensive exploration of personality.

Miriam would gladly forfeit his comradeship for the certainty of seeing his world of ceaseless becoming exchanged for one in which should be included also the fact of being. 
Being versus becoming. Becoming versus being. Look after the being and the becoming will look after itself. Look after the becoming and the being will look after itself? Not so certain. Therefore it is certain that becoming depends on being. Man carries his bourne within himself and is there already, or he would not know that he exists (IV, 362).

The Quakers in their simple approach to God and Reality have found their way to the centre of being, each speaker remaining at home in full possession of his individuality even to the farthest reaches (IV, 447). But both ways of approach, Dorothy Richardson reminds us, the inner and the outer, should exist together in the ideal human being (IV, 182). Strange that the Quakers should have discovered this too, engaging in private as well as publicly their method of approach to reality. One should pause in becoming, and be. This for Miriam, as Dorothy Richardson wishes us to see, is Iife-Reality--the essential something that busy becoming Hypo and his associates refuse to seek and fail to recognize, and so, irretrievably miss. 
CHAPTER THREE

SOUND MND FICLURE

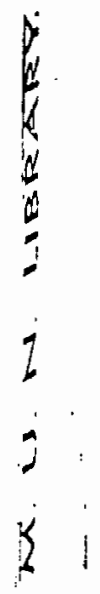

$-46-$ 
Pilgrimage may be the mystic quest that John C. Powys so enthusiastically applauded in 1931; it may be a vivid re-enactment of Dorothy Richardson's own pilgrimage; it may be a revelatory chart of the astounding advances made during the Victorian Age with its accompanying conflict and doubt, serenity and faith; it may, in fact, be the mystic's answer to that doubt--a routing of the challenge of science; it may be a pioneering dip into the "newer science" as psychology attempts to peer into the yawning abyss of the hitherto unexplored, Inner consciousness of man. Pilgrimage may be all of these, but in addition, Pilgrimage is a unique presentation of life wherein Dorothy Richardson, to point up life's many significances, adopts the unusual device of treating her characters' responses to the arts.

Graphic art, music and literature form a triple thread running through Pilgrimage, from the moment we meet Miriam in Pointed Roofs, packing for her journey to Hanover, until we leave her in March Moonlight writing a novel "alive all over." Dorothy Richardson uses art as a means of presenting character; through a review of the literature firiam reads or is aware of she traces Mirian's mental and spiritual growth and in doing so criticizes the entire literary field; while 
through mugic she reveals other aspects of Miriam's pilgrimage, and throws a scornful searchlight on the pretences of a conforming society.

In this chapter I shall be concerned with music, the accompaniment that makes audible the flow of life as Dorothy Richardson seeks to convey it, and with the graphic arts, a metaphor for Dorothy Richardson's pictorial method of outlining and presenting character.

I shall therefore briefly indicate the significance of music as played and experisnced by Mirian, and devote the major part of this thesis to a discussion of the contribution of art and literature to Dorothy Richardson's unique method of presenting life.

A new vista of emotional experience opens for Miriam when she is introduced to music in Germany, a country unashamed to show its deep enjoyment of the arts. Miriam had been nurtured in a home where music, regarded as a social asset, was played and enjoyed, but never with such complete surrender as experienced by the Germans. Music, she suddenly discovers, is not something she plays embarrassedly before her father's guests, fingers like sticks, angrily hitting the keys; music is something to glory in. For the first time Miriam experiences the wonder of losing herself competely in music, emerging fresh, strong and revitalized.

During her first evening at Waldstrasse, Hiriam attends an informal playing of musical pieces by the pupils, a 
Vorspeilen, during which Miriam experiences one of her deeper "illuminations," and from that moment her playing and her listening undergo a significant change. Even when she returns home, the strange influence of the music is felt. During a relaxed evening listening to music with her family she suddenly "seemed to grow larger and stronger and easier as the thoughtful chords came musing out. [. . After a while everything was dissolved, past and future and present and she was nothing but an ear (I, 205)."

Soon it becomes an agony for Miriam to sit through a musical performance wi thout surrendering immediately to its mystic appeal. R.H. Scott-James describes one such moment:

In listening to music at a concert she was aware of "passing along the surface of its moments as one by one they were measured off in sound that had no longer held for her any time-expanding depth," tormented by knowing that her "authentic being" was far away in her consciousness, till suddenly a single flute-phrase, emerging unaccompenied, ... spread coolness within her, refreshing as sipped water from a spring. ${ }^{1}$

But music for Miriam is not just a means of transition to her inner being; it is a medium used by her to flush out shallow pretences or plumb the unsuspected profundities of those she meets; thus she passes judgment on Hypo for profanely seeking a hidden laugh in Bach (though "the smiling musician," as ie is called, may very well have tucked in a chuckle), and on the Quakers for expressing the fullness of their souls in sacred song. Music can flow gloriously forth in a cold, drab room; it can be stifled to an empty tinkling in a home 
of frivolous luxury. The piano becomes to Miriam a symbol; Miriam puts, as she listens to the piano being played, a stamp of approval or rejection upon the owner or the performer. ${ }^{2}$ Wherever Miriam moves she seeks a piano, and finds one, except at Flaxman's (where the only music is drunken songs of caterwauling), and from Flaxman's she flees. At Mrs. Bailey's the piano in the large drawing room is exclusively hers on Sunday mornings, making Sunday, the day she enjoys most in the week, a truly wonderful occasion as she finds herself in music.

But all do not share Miriam's deep joy in music, she disconcertedly disovers. While visiting Harriet she plays Beethoven's Largo for an unappreciative Mr. Tremaine.

Through its tuneful raging she could hear the steady roice and see the steady shining of the broad clear light. [..] She got up charged to the finger tips with a glow that transfigured all the inanimate things in the room (II, 28).

Though Miriam has been transported Mr. Tremaine has heard nothing but noise; his eyes smile, and his mouth feels for compliments, but some part of his being has remained uncreated, undeveloped--still undiscovered.

Music, however, accompanies Miriam throughout her pilgrimage. The finished, polished strains of Mozart rise through the still air of Oberland, where the world's élite and surfeited gather to renew themselves in winter fun in a world where eternity becomes visible in mountain and snow; but it is Beethoven's calm, pure notes that peal out over the 
peaceful landscape at Dimple Hill, as a cleansed and refreshed Wiriam pauses to join the Quakers in quiet contemplation.

Beethoven and Bach, Mirian thinks, are experiences and adventures of the solitary human soul; but Wagner in all its moods is everybody speaking at once. Of all music, Wagner best can reach the heights and plumb the depths of human emotion, she feels, as having just returned in an exalted mood from Oberland to her beloved London, she prepares for an evening at the opera with Jypo and Alma Wilson. Dorothy Richardson uses the occasion to comment on the artificiality and snobbery of the dress circle in the opera box. The opera box, having long outgrown its earlier necessity, has become a symbol of social importance; and the social opera-goer resplendent in evening attire is the "cliff-dweller" of the aesthetic world, clinging to his social heights in his box on the sides of the opera hall (Covent Garden), unable to get full view of the wondrous spectacle on the stage, or hear in all its fullness the glorious music of the opera; he sits there bored, important, correct, attending in obeyance to the routine of the opera season (IV, 169-170).

Music as used by Dorothy Richardson in Pilgrimage can be an audible barrier between those holding discordant views of life, or a melodious bond between those whose spirits are in tune with one another, as Miriam discovered when she heard Vereker play the Chopin ballade or Oberland; music may be an effective means of reflecting a mood, depicting an atmosphere, 
or subtly condemning the empty conventions of an equally empty society.

The bright, lilting duets played by the young Miriam and Harriet not only indicate the level of their musical education and interpret the mood of the girls and of the occasion, but reveal the close relationship existing between these two sisters.

On the other hand Alma's affected rendition of Chopin reveals her intellectual snobbery, driving Miriam into a rage as she plays the piece at her audience, every line of her face and body proclaiming it the right sort of music. Her way of holding back the third note for emphasis where there is no emphasis is like finding a wart a.t the dropping end of a fine tendril, Miriam angrily fumes, while the audience applauds in subdued reverence. Miriam is torn between two emotions, a desire to let Alma know she is wrong, and a sense of outrage at the distortion of Chopin. This description of a musical evening at the Wilsons' is an indirect comment upon Alma and the attitude of herself and her literary friends towards music, and indeed towards life itself; it presents the pleasant, melodious though artificial atmosphere of the 'cultural' background against which the Wilsons insist on living; and it is, as Mliriam ruefully permits it to be, a revelation of her character as she fights the desire to let Alma know. Whe omniscient author does not overtly intrude in a psychological novel, but by means of these and similar 
instances Dorothy Richardson nevertheless has her say.

In writing a psychological novel, Dorothy Richardson was obliged to deal effectively with the problem of characterization. Character, says Daiches, ${ }^{3}$ is a process not a state. Man's character is his reaction to his environment actual or potential, and character, he continues, can be presented only through some attempt to show this process at work, completion of character being judged by the degree to which its potentialities are realized.

Traditionally, though not exclusively, two methods of characterization have been included in the novel: presenting a rounded description at the point where the character is introduced into the story, or permitting personality to emerge through the character's reactions to chronologically arranged events. Recent methods have chosen to Iook into the consciousness of the character. The stream-of-consciousness method must be the work of the author. Here the author separates consciousness from chronology of events, investigating to the very end, remote, mental associations and suggestions without waiting for time to malke them actual, thus achieving through 'depth' what others do by extension. In other words the stream-of-consciousness author presents character outside time and space. The final character may differ from the primary presentation as he reacts, positively 
or passively, to the impact of events, but the earlier character will be valid for earlier situations.

Dorothy Richardson chooses to reveal her characters a little at each time of meeting, using what I should prefer to call the 'sketch book' method, in which she uses the technique of the draughtsman or the painter. The barest outline of a character is given at the initial moment of meeting. He is 'roughed in' sufficiently to give him identity, lines and colour being added at each subsequent meeting, until finally he stands complete and fully drawn, awaiting only the signature of the artist, which Dorothy Richardson claims to have given already through her style of writing. It is the stopping by the artist to describe people that spoils so many novels, Dorothy Richardson complains (IV, 613-614). Characterization in Pilgrimage, then, is a slow accumulation of impressions. Just as in everyday life, one does not learn immediately the depth and height of another's personality, but, through the slow process of unfolding, discovers which traits are habitual, and how the character reacts to external and internal stimuli. Characterization is the slow evolvement of a person, as we inevitably approach the being that he is; characterization is a becoming that finds its end in being.

Our first impressions of a character are deepened, erased, modified; some remain only a single first impression. But is life not like that? 'The indefinite 'they' move into 
our ken or orbit, and out again--some, like a comet, zooming past, leaving a brief trail of brilliance that aerves to deepen the returning gloom after its passing. In just this way Miriam quickly accumulates and discards acquaintances and friends, retaining only a minimum to sustain her over the many years--they appear, recede, and, occasionally, re-appear.

The medium Dorothy Richardson uses is raw material at first: we do not see character through 'the eye of the novelist' but through the consciousness of a young sensitive girl, not yet a writer, though potentially one. Does Miriam become more perceptive over the years? Is our cognizance of character, viewed through Miriam's consciousness, progressively deeper as we move through 'chapter' after 'chapter' year after year? The characters seem to change; not only do they reveal more and more of themselves through their response to environment, but Miriam appears to grow away from or towards them as she progresses in her quest. As a character's attitude towards life is presented Miriam measures each mentally with an ever-lengthening yardstick, making ever-increasing demands as she, herself, matures, often to find them wanting. Imerson eventually is rejected, the Iycurgans out-grown, and, not surprisingly, liypo is overtaken and discarded.

Gradually Dorothy Richardson ekes out her information, frequently in retrospect or 'flash back,' as Dorothy 
Richardson's powers of apt description are brought into full play, here using a brief sweeping statement (especially in Miriam's younger days), here a lengthy paragraph consisting maybe of one or two periodic sentences, and there dribbling information sparingly over several pages. Further information can be gleaned from Miriam's private assessment, negative or positive, of those she meets, and from the close scruting of their physical features, foreheads of men, for instance, often being used as a key to their hidden characters.

Dorothy Richardson's method of characterization may catch the reader unawares, much to his annoyance. He may dislike the extra effort of totting up impressions to get a sum of the whole and may settle for some dim evaluation. Dorothy Richardson, as mentioned earlier, does not laboriously spell out the character when he is introduced; instead she gives a few deft flourishes of an 'impressionistic' pen and her character gradually 'appears.' Not until the character is complete and ready to make an exit does she lay down her pen. In Pointed Roofs we lean over Dorothy Richardson's shoulder and leaf through her literary sketch book. Her Gertrude, who does not appear again in the story, is an exercise in character portrayal. With painstaking accuracy Dorothy Richardson sketches. The head--forehead, hair, eyes, shape of face (square or oval), the hands, the slender back or lumpish shoulders, all seen through the eye of an artist, reflect the character Dorothy Richardson wishes to portray. 
The pen sketches she gives of the men at Mrs. Corries'--hating foreheads, open mouths masticating food, vacant eyes--reveal exactly how Miriam regards the male. At first Dorothy Richardson views people, at eye level, from the neck up; later waist-high, then full-length against a background. To digress slightly--the tree-shaded Iondon streets may be etchings; the pastoral scene at Dimple Hill, the pristine beauty of the oberland ${ }^{4}$ mountains would be in clear-toned water colours; and her masterpiece in oils would be the portrait of her own nude loveliness in contrast to Hypo's unloveliness,--the flesh tones depicted with an artist's keenly observant eye. I could be a musician, a painter, a writer, Miriam once remarked.

Michael Shatov, ${ }^{5}$ who first appears as a Russo-Jewish student, gradually 'takes shape'--his frock coat, his posture when walking, leading with a pointed beard, elbows on table shouting at a waitress, sucking tea through a lump of sugar, head bent over a book, remonstrating in a tired gentle voice over some philosophical tenet. Gradually the distinctive marks of the Jew are superimposed over those of the scholar: 'I am a Jew,' to Miriam when he kisses her; his Jewish attitude towards race and women, his phylactery, his dancing before the Lord on the Roscorla lawn at sunrise, until, there he is, truly Rabbinical. A few more strokes and the pointed French beard has become long, bushy and patriarchal. Stroke by stroke the Jew glimpsed at the outset has been completed-- 
the portrait is done.

Or, to borrow a metaphor from the motion picture industry, we start with a single image on which an almost imperceptible change has been imposed, then a similar slight change on the next image, and the next, until, when flashed on the screen, the image seems to move. But these are not 'silent' sketches or 'films.' In keeping with cinematic progress, the conversation of the characters and Miriam's commentary on them is both audible and revealing. Perhaps a quick 'run' through the pages of Pilgrimage would show exactly how Dorothy Richardson 'characterized' Michael Shatov。

Miriam sees Michael first, when introduced by Mr. Rodkin, as a "little dark frock-coated figure" "in attitude of courteous obeisance" "controlledly waiting," "his lifted head, the extraordinary gentleness of the white tremulous, determined features, the child-like openness of the broad forehead, the brilliant gentle depreciating eyes, familiar handsome unknown kindliness gleaming out between the high arch of rich black hair and the small black sharply-pointed French beard (III, 22-23)." (The artist's hand has sketched a head). This is not merely a physical description but a portrait of a Renaissance scholar, courteous, gentle, intelligent, determined.

From that moment Mirian and Michael are students together, exchanging photographs of their minds. At the end of the lesson Michael plunges lightly upstairs, brumming in his 
deep voice (III, 23). We are required to note his immediate attention to study, his walk, his little idiosyncrasy of "brumming," then his accent: "British Moozaum" and "all these leeter-aytchoors" (III, 24-25).

Next day we are given a second look, a waist-high view, this time limited to his dress. "Had there been yesterday that glow of crimson tie [. . ] ] under the point of his hlack beard and the gold watch-chain across the blackness of his waist-coat?" And his posture; he is hunched crookedly in his chair with his head thrown up and listening towards her, with his eyebrows raised as if he were singing and, on his firm small mouth, the pursed look of a falsetto note (III, 24). Pinally more minute detail "There was a ring on the little finger of the hand $[$. .] pale old gold curving up in a small pimple of jewels [. - ] giving to his youth a strange look of mellow wealthy middle age (III, 25)."

Michael has been established; it remains only to add to this image to make ilichael 'move.' Miriam uses ear as well as eye. Already she has discovered that he speaks Norman English in German idiom with an intonation that she supposes must be Russian (III, 28). She marks another idiosyncrasy, his habit of saying "Ach-na" (III, 27).

Then we are given his age: Max Nordau, a marvellous white-haired old man had made Shatov at 22 feel old (III, 29). Miriam's keen ear next catches the strange inflection of "his curiously woven argumentative sing-song tone, which sounded 
as if he were talking to himself, though it was broken here and there by words thrown out with explosive vehemence (III, 29)." Then his lauph is described, "an easy deep bass chuckle."

When Miriam sees him in outdoor attire waiting to be escorted to the British Museum she is horrified. This time the portrait is full-length. The young man Miriam sees leaning against the lampost is:

a shabby, sinister-looking Tottenham Court Road foreign loafer, in yellow boots, an overcoat of an evil shade of brown, and a waiter's black-banded grey felt hat. [...] He was gloveless and in his hands, grimed with walking in the winter streets, he held a bag of grapes which he ate as he talked, expelling the skins and flinging them from him as he walked. . . He looked just simply disreputable (III, 54).

At the museum Dorothy Richardson shows Michael hurrying along at Miriam's side, "beard forward, his yellow boots plunging in long rapid strides beneath his voluminously floating overcoat (III, 57)"; while in the refreshment room we see him placing his "grubby clasped hands" on the table and bellowing at the waitress to bring him tea, which he proceeds to sip "in neat noiseless sips" through a lump of sugar held between his lips (III, 63-64).

Dorothy Richardson gives us several quick sketches of Michael, each one revealing some aspect of his personality. She poses him as a solitary little figure forlornly waiting for Miriam in the rain the day she returns from her Christmas vacation (III, 107)。 She portrays him as Michael, the lover, 
waiting: for Miriam in the evening, silently re-affirming his love with a single rose (III, 192); or standing, stricken, with pale quivering face, l'alteringly confessing some episode of his past, earnestly pleading that he did not lnow Miriam would one day come into his life (III, 204). But perhaps the most revealing view is that of Michael as he walks one day with liriam. Stopping suddenly at the sight of a woman trying to lift a heavy perambulator up some steps, he orders an already-exhausted Miriam to help the woman, while he strolls casually on. It is this attitude, so typical of his race Miriam thinks, that eventually costs him Miriam. She cannot marry a man who accords her so little homage (III, 26I).

In the role of host, entertaining his Russian friends, the Iintoffs, Michael sits at head of table with his glowing Hebrew beauty, his reverberating voice expressing him, untrammelled, in the poetry of his native speech (III, 29l). Iater Miriam pays tribute to his rich dignity and simplicity as he reads the psalm at the Roscorla supper table. Next morning, believing himself unobserved, he dances, "a lonely little Jew, jigging about" on Rachel Mary's lawn, "solemnly, clumsily, and yet with appealine grace, the heavy bulk of his body redeemed by the noble head, face uplifted to the sky, beardpoint extended," "rejoicing in the Lord with the tablets of the Lord invisibly held within his swaying arms (IV 520)." Dorothy Richardson has given the portrait the merest touch of pathos here. 
Finally it is all brought together in a concluding image reminiscent of the first view of Michael:

fresh from ceremonial tubbing, in sabbath frock-coat topped by deep crimson tie visible

[. - $]$ beneath the beard no longer trimmed to a worldily point and already on the way to becoming an oblong bush, rabbinical, the massed fine strands of his grandfather's pale gold watch-chain garlanding his breast, and the antique ring in place whose pimple of seed pearls rising from its bed of blue enamel set in graven gold, together with his air of leisure and availability . . . so vividly recalls those first far-off days at Tansley Street (IV 597-598).

Dorothy Richardson has brought Michael Shatov 'home.'

Mrs. Bailey has been given similar treatment. Ieft penniless in Weymouth with a family to support (we are told this at the end of her story when Dorothy Richardson probably feels that having come to know Mrs. Bailey, we should learn something of her background), Mrs. Bailey not only becomes a prop to her family but to her boarders and to Miriam as well. As she crowds scratched and broken bric-a-brac into her own room to ciear the way for others in her house, so she seems, out of her deep understanding and her compassion for humankind, to draw to herself the cares and problems they cannot handle themselves. Miriam recognizes this in Mrs. Bailey at once, and though she goes to share a flat at Flaxman's Court, yet she is drawn back to Mrs. Bailey again, seeking some warmth and reassurance that Miss Holland fails to give. 
On first moving into Tansley Street Miriam is relieved to find Mrs. Bailey looking as she had looked during their previous interview, "same girlish figure, and the same smile triumphing over the badly-fitted teeth (II, II)." Mrs. Bailey does not keep watch on one or speculate about one's private life (II, 17). Her little mannerisms make her very real: we see her making "a little dab at Miriam's knee," "interlacing" her hands, "brushing her skirt with her handkerchief"; we hear her coming up a flight of stairs clearing her throat, saying "mts" and "youce." Quietly, unobtrusively, under her ceaseless supervision, the work of the household goes on.

So effectively does she efface herself that Miriam is, one day, startled and concerned to learn that she plans to turn her home into a genteel boarding-house, and for the sake of Susie and her sister, to move a step further up in the world, Miriam is surprised at her keenness, her courage and her ambition. Just as unobtrusively Mrs. Bailey puts her plan into action. We see a new Mirs. Bailey "in a refined little voice, throwing a proud shy glance toward Miriam from her recovered place behind the tea tray, cheeks flushed, eyes sparkled (II, 328)." But there are dark days when she lies prostrate in her cluttered room assaulted by her headaches, with "drawn face, fever flushed and wild bright eyes." There are days when she is forced to take economic measures, to turn down the gas to make ends meet (III, 79-80). 
But she somehow forgets to present a bill to an indigent boarder, and she never fails to take her place at the dinner table, cheerfully piling the plates high with savoury, filling food.

Of all who knew her, Mir. Gunner, twenty years her junior (is Dorothy Richardson thinking of her husband Mlan Odle here--many years younger than she?) has the true insight to see what is behind her "half-dyed hair and terrible ill-fitting teeth. Glorious. . . She was a girl, modest and good. She stood decorated by a miracle." MIrs. Bailey has triumphed; "justifying her everlasting confident smile (III, I7)."

Once again the 'portrait' is complete, but the facts, the hints, the suggestive images are eked out over six hundred pages. The 'conventional' author, perhaps, would have braked the machinery of the novel and given much of this in several brief paragraphs.

As previously mentioned, Dorothy Richardson contends that it is just that stopping by the author, to describe people, that spoils so many books. Obviously she does not err in this respect in presenting Miriam to the reader. She extends the major details of Miriam's physical appearance over several volumes, unobtrusively sketching in a line or adding a touch of colour but ensuring that the picture eventually is complete. 
In doing so Dorothy Richardson must cope with another added problem. Pilgrimage is written from the point of view of a single consciousness--Miriam's. How then does Miriam's consciousness portray Miriam? Dorothy Richardson resorts to several devices. Miriam listens to comments by others on herself, she looks into the mirror, she day dreams, she examines her hands, she visualizes herself as others might; for instance, she describes her nude loveliness as she imagines Amabel would have seen her.

In Pointed Roofs we obtain a vague impression of Miriam's appearance from her sisters--"not plain," "the best shape face and the best complexion of any of us"; to their cook she is "The light of the house" with her "happy, pretty face," while her mother considers her much too attractive to go about alone. Her voice at times is indistinguishable from that of her three sisters, but they think hers is "really richer" (I, 23-25).

"I'm pretty," murmurs Miriam. She does not look into the mirror.

Not until page forty-eight do we learn her family name, Ifenderson. We learn that her eyes are weak as she adjusts her pince-nez (I, 55). Her near-sightedness is emphasized again when Pastor Lahmann examines her glasses, and looks into her 'lame, lame eyes.' "You were vairy, vairy blonde, even more blonde than you are now?" he asks (I, 129).

Somewhat later she comments on her appearance in the mirror. 
She had finished struggling with her long thick hair and put hair pins into the solid coil on the top of her head and tied the stout double door-knocker plait at her neck, she put on her rose-madder blouse. [: . .] "How jolly I look," she thought, "Jolly and big somehow. [: . I I am German-looking today, pinky red and yellow hair. But I haven't got a German expression and I don't smile like a German..... silly baby face (I, 150-15I)."

Back in England, when they are riding home from

Wordsworth House on the bus one day, her mother asks her to sit back and not hlock the view. She is "such a solid young woman" ( $I, 198)$.

Throughout Pilgrimage Mtriam is conscious of her hands. Dorothy. Rtchardson uses the quiet musing of Miriam to describe them and what they mean to her. She pauses in her reading of two-penny books to examine her hands.

They were not 'artistic' or 'clever' hands. The fingers did not 'taper' nor did the outstretched thumb curl back on itself like a frond-like Nan Babington's. They were long, the tips squarish and firmly padded, the palm square and bony and supple, and the large thumb-joint stood away from the rest of the hand like the thumb-joint of a man. The right hand 6 was larger than the left, kindlier, friendlier, wiser. The expression of the left hand was less reassuring. It was a narrower, lighter hand, more flexible, less sensitive and more even in its touch-more smooth and manageable in playing scales. It seemed to belong to her much less than the right; but when the two were firmly interlocked they made a pleasant curlous whole, the right clasping more firmly, its thumbs always uppermost, its fingers separated firmly over the back of the left palm, the left hand clinging, its fingers close together against the hard knuckles of the right. 


\begin{abstract}
It was only when she was alone that she came into possession of her hands. With others they expressed her by their size and their lack of feminine expressiveness. No one could fall in love with such hands. [. . They would wither, --but the bones would not change. The bones would be laid unchanged and wise, in her grave ( $I, 283) .7$
\end{abstract}

With meticulous detail Dorothy Richardson has given us a 'model' of Miriam's hands, cast in words.

We learn of her pretty teeth in Honeycomb when one of Mrs. Corrie's guests tells her that she ought to smile more of ten ( $I, 429)$; we find she has a rose-leaf complexion and golden hair in the Tunnel (II, 161); and she is 'stock size' (II, 160). In Interim, when she visits the Brooms, she shrinks from her "ugly, inexorable cheap clothes, her glasses, the mystery of her rigid, stupidly done hair (II, 318)." In Deadlock Michael Shatov considers her 'gracieuse' when Mr. Rodkin asks him if he considers her pretty, while women consider her 'broadminded and plain' (III, 70). Her eyes are the most beautiful feature of the portrait in Revolving Lights. Here Miriam hunts out her hand glass and consults her unknown eyes, to discover that her eyes are brown not grey, with a web, thorny golden brown, round the iris. She is a goldy-brown person, not a cold grey, with half a chance, goldy brown and rose. The whites of her eyes are pearly grey-blue (III, 337).

In Dawn's Left Hand we are given a more intimate full length view in the nude. 
With the eyes of Amabel, and with her own eyes opened by Amabel, she saw the long honeycoloured ropes of her hair framing the face that Amabel found beautiful in its 'Flemish Madonna' type, falling across her shoulders and along her body where the last foot of their length, red-gold, gleamed marvellously against the rose-tinted velvety gleaming of her flesh. Saw the lines and curves of her limbs, their balance and harmony. Impersonally beautiful and inspiring (IV, 231).

This one we feel is done in oils, richly, almost lavishly, bringing out the pearly-toned curves.

In the psychological novel the omniscient author cannot intrude to interpret $\mathrm{his}$ characters to the reader--the characters must be permitted to do this of their own accord, and in this particular work we are dependent upon the eye, ear and memory of one character--Miriam. Here we have dealt mainly with one aspect of the presentation of character. An interesting study also could be made of the revelation of character through thought and speech, but, in a work of limited size such as this, we deemed it fitting that Dorothy Richardson's unique method of description should receive prior treatment. 


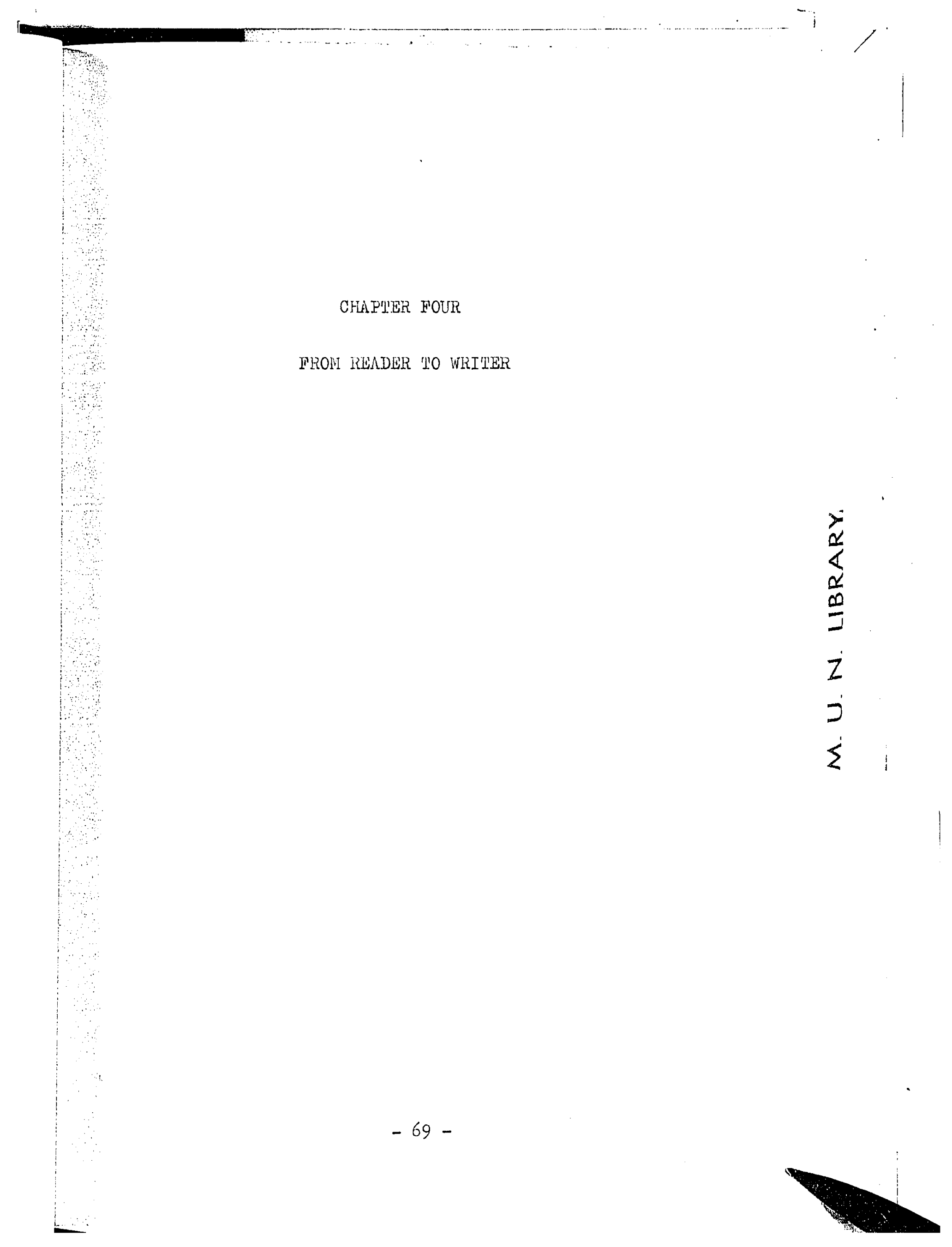


By giving us Miriam's continuous stream of responses to people and situations, Dorothy Richardson has permitted, or compelled, us to participate in Miriam's metamorphosis from adolescence to middle-aged maturity. Youthful Miriam, so quick to assert her opinions, so hasty to condemn, so swift to deny, contradict, discard those who fail to meet her requirements, so agonizingly enthusiastic in her beliefs, yields to a liliriam noticeably more understanding, more meditative, as she reaches outward to broader horizons, cluttered as they often were with lectures, conversations and travel, until she learns to clear them of the trite and the unfruitful; and she in turn yields to a Miriam reaching ever more deeply inward, seeking in the solitude of those twilight regions a complete inner sustaining self.

But in attempting to portray Niriam's ever-developing consciousness, Dorothy Richardson must delineate and define the environmental influences at work upon that consciousness, among them, books and all aspects of literary efforts. Here Jorothy Iichardson very opportunely carries out a double intent: she traces the development of her character Miriam, and she gives frank expression to her acute dissatisfaction with the novel available to the reader at that time, in fact with the entire craft of writing as it would have appeared to Miriam 
As one 'chapter' after another is added to Pilgrimage over the years, it expands into a critical commentary on books, on the art of writing, on man's spoken and written thoughts designed for presentation to an intended audience. Pilgrimage becomes a private Review (as the one Dorothy Richardson wrote for was a published Review), based on observations spanning a lifetime from Dorothy Richardson's childhood to her more than three score years and ten; in short, this becomes a logical exposition on the craft of writing that runs threadlike through Pilgrimage giving it coherence and unity, yet which can be lifted from the novel complete in itself.

Imploying Miriam as our guide, Dorothy Richardson takes us on a critical tour of the literature of the ages. She examines a broad sweep of the novel: the early and later romantic, the picaresque, the historical and the more recent psychological and scientific; she shuffles through the periodicals, pamphlets, newspapers, magazines and journals, whether medical, scientific or political; she reviews samplings of drama and poetry from the earliest days; even the formal word of the lecture theatre she examines critically and grades accordingly. None escape her comments. She pats and slaps, not indiscriminately, though with deliberate unconcern for well-earned or ill-won public acclaim. Leaving the obvious to the critic of the day, Dorothy lichardson is content to touch with a light, but stinging, flick of her pen the f'atal 
weakness of each work she examines.

Miss Richardson surveys not only the work of art itself but its triangle of co-ordinates, ${ }^{I}$ the author, the readerpublisher-market, and the material available for content. What impels an author to write? she queries. Some shoddy purpose? An ambition to write a quick-seller by revealing intimate incidents of the author's life? A love of the written word? Or the desire to set straight the crooked ills of the world? Dorothy Richardson does not permit to escape unscathed a reading public who can content themselves with a diet of false 'pap' disastrously lacking in mental nutritives, nor the publisher, eager to cater to this demand, with a mercenery eye on a market where quantity supersedes quality. Furthermore, there is no guidance to selection of books. How do people find books? liiriam wails.

In attempting to formulate and perhaps solve the problems she sees facing the dedicated writer, Dorothy lichardson rightly begins at the beginning with the reader's awareness of books. The mind that will mirror this awareness is that of Miriam, young, unsophisticated, but not unlettered or untutored; she has had an excellent grounding in literary classics, in drama and in music-her father has seen to that. Dorothy Richardson has selected a girl with a sensitive, probing mind, a mind that will become the touchstone with which Dorothy Richardson tests the metal in the utensils of her craft. 
Miriam's dawning comprehension of books, her absolute involvement in the written word, her ever-broadening view and subsequent frustration, her rare moments of illumination when she seems to have discovered The Book, her failure or success as she seeks stimulating inspiration from those with whom she associates is a commentary not only upon the ineptitude or otherwise of the 'author' but, in addition, upon the apathetic attitude of the reading public, its unrecognized bewilderment, its blind unawareness of mental malnutrition and its passive acceptance of any literary fodder proffered by that revered being--an author--even though mental indigestion become a chronic disorder.

As she continues her pilgrimage through thirteen 'chapters', Miriam becomes increasingly aware of these things. These are the flaws in your books, she flatly states. They are created by writers with cold logical minds, concentrating on plot or some traditional element at the expense of the essential Something--the 'reality' of life--merely skimming the surface, all of them writing from a masculine point of view, missing so much that can be seen, grasped and expressed only by the feminine consciousness.

In the first book Pointed Roofs, on the last morning before leaving for Hanover, where she hopes to alleviate the financial situation at home by, at least, contributing to her own support, Miriam is suddenly conscious of her books, intoning the names on their well-bound spines on the shelf: 
Scott, Villette, Longfellow, Holy Bible. She determines to come back and read them some day, more carefully to explore their individuality. At this stage books are merely titles and bindings to Miriam,--the appeal of the physical to the naked eye; she cannot differentiate one book from another. She has packed some; she cannot remember which or why, each volume merely a member of the common noun "books"; but a book, she guiltily feels, should be read carefully for itself alone. Harriet has discontinued reading her long-outgrown juvenile selection. "Yink grink binks " she irreverently calls her books ( $I, 23)$, but Mirjam, perhaps without realizing it, at this stage has embarked on a reading quest that will find its culmination in her determination to write a novel eliminating the defects of those she has read. There is little inspiration from books for Miriam in her German environment; the selection of English books is pitifully inadequate, though the pupils read schiller and Goethe in German. Miriam's class is reading Misunderstood, "so sweet and beautiful[a]book" to the German girls, but a book she and Harriet had banished and wanted to burn in their early teens. What guides a person to a book? Miriam seems to ask. Does one simply accept what is being proffered? Or what criteria should one use in selecting a book? There is no immediate answer. One night in Hanover, before relaxing in sleep, Miriam's hungry, tormented mind surveys the Henderson bookcase at 
home, recalling Greek classics, science, history, philosophy, poetry, an imposing array, all waiting to be explored, but no novel, as we understand that term. She recalls the titles, picturing and mentally feeling the shiny brown gold-tooled back of Motley's Rise of the Dutch Republic and the hard graining of the red-bound Chronicles. Vaguely she remembers pictures inside but no literary content. Books still mean outer binding, backs and titles. She wishes she had read more carefully.

At Wordsworth House, a boarding school in industrial North London, Miriam's growing acquaintance with books has been halted temporarily in a mental backwater. The only story books among the rows of volumes in the classroom is The Story of Adèle, with hard unpleasant covers bound in lobelia blue cottony material frayine at the corners, the lower half faded by exposure to the sun. But there is nothing in the book that really satisfies; it consists mainly of empty words and phrases running prettily on and on, until without warning the end is reached. She has simply finished the book. Miriam's attention is fleetingly caught by Fleurs de I'Eloquence in shiny brown leather with gold buds and tendrils, fresh and new, al though the parchment pages are yellow with age (a revelation that Miriam still is attracted by exteriors), but the 'fleurs' are too brief, particularly one on the French court by Froissart, which ends just as the narrative captures her interest. She carefully

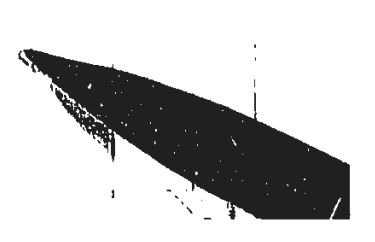


considers The Anatomy of Melancholy, whose title alone, ${ }^{2}$ will be enough to keep her going at teatime, she thinks, as she rolls the words out in sing-song fashion, Anat-omy of Mel-ancholy, enjoying its euphonic appeal. Then she realizes more soberly that this book

would take so much reading, on and on forgetting everything; all the ordinary things, seeing things in some new way, some way that fascinated people for a moment if you tried to talk about it and then made them very angry, made them hate and suspect you (I, 226).

Dorothy Richardson takes advantage of liririam's situation at Wordsworth House to discuss such thought-provoking books as Robert Burton's Anatomy of Melancholy. She shows us through Miriam's observations that even when one is prepared to delve deeply into a book and discuss its ideas, one finds that others are disinterested or suspicious of thoughts differing from their own. Whe topic Melancholy may have been shunned by some, but lifiriam undoubtedly would have been fascinated by the third partition of the book on love melancholy and religious melancholy where she might recognize her own symptoms and find a cure.

Dorothy Richardson here seems to have given liiriam's predilection for titles an amusing little tweak, and her preoccupation with titles is further emphasized as she comments mentally on the books--mainly by Charles Dickens--brought in by the pupils to read during meal hours. Miriam thinks it would be impossible to read a book with 
such a title as Nicholas Nickleby--repetitive, empty-sounding like a child's singing game or the vulgar nouveau riche Mrs. Corrie's "stiboo-stibee" with her children. David Cooperfield would be all right, and The Pickwick Papers, but as for Iittle Dorrit, A Tale of Two Cities, The Old Curiosity Shop, there was something suspicious about these too (I, 227). Dorothy Richardson herself is impatient with inept titles of characters and books, holding that a title should be meaningful as well as appealing. She may have wanted Miriam to seek some unrecognized quality behind the title.

And supposing books had no names, Miriam suddenly thinks. Does knowing a name in advance, having received it glowing with praise or drooping in condemnation, influence one's enjoyment and interpretation of a book (III, 65)? The circumstances under which one is introduced to a book may adversely affect one's reception of it. Miriam balks at a book proffered by the clever, anecdotal, pious Dr. Salem 0ldfield: the sight of it suggests his sledge-hammer sentimental piety.

Through Miriam, Dorothy Richardson is taking a close look at the reading public. Fler own Pilgrimage did not receive a very enthusiastic response. She was conscious as she wrote Pointed Roofs of the urge to share her work with someone; she knew hopes of publication were small ( $I, 10)$. And though she yielded to the critic J.D. Beresford (at whose house she wrote the book) and submitted pointed Roofs to a 
publisher, it was rejected and would have remained so had not Beresford persuaded Edward Garnett to publish it in 1915. Dorothy Richardson is in the unique position of being able to comment directly on the current market for books in each succeeding 'Chapter' of her Pilgrimage. Meanwhile she shows Miriam's beginning search in books for an elusive Something that will satisfy an, as yet, unidentified inner need. The answer may be found in a religious book, Miriam thinks, in John Bunyan's Pilgrim's Progress or Whateley's Line Upon Line. Embarked upon a pilgrimage herself, Miriam is attracted to Bunyan's Pilgrim. But these books are not keyed to modern minds, she decides. Besides, Archbishop Whateley of the "chaste and ready wit" is a "great gardener"--an incongruous combination, Miriam feels. Maybe he understands gardens better than he does bewildered young girls. She considers a meditative book: Preparations for Holy Communion. Again the beautiful binding attracts, gilt-edged with a little gold cross in the right hand corner. But this time the book is too modern, the author is still alive! This perhaps is the first indication by Dorothy Richardson that one reads an author not a book, for Miriam turns away with a feeling of shame that the author, through his book, will see and hear her guilty thoughts as she reads, though he would, of course, understand modern doubts. But the task of self-examination of sins past and present in thought, word and deed is too onerous for Miriam. How can one cleanse one's memories? 
Books on morality, Miriam concludes, increase one's frightened sense of guilt without in any way assuaging it.

Finding little promise of mental fulfilment in books at Banbury Park school, Hiriam turns to the newspaper, an enlightening experience for her as she becomes increasingly aware of the potency for good that lies in the well-directed printed work. What a source of golden information a newspaper can be! She thinks that " . . anybody could know as much as the men sitting in the armchairs ${ }^{3}$ if they chose, read all about everything, written down for everyone to see ( $I, 243)$." But something is wrong. Newspapers--the freedom of the press for which rilton was imprisoned--the Areopagitica about which history said so much--newspapers sounded like "angry men with loud voices" (I, 243). One wonders whether Miriam's response here is a valid one; she requires that newspapers be femininely subjective rather than polemical.

With the discovery of Banbury Park's"Circulating Library, 2d. weekly," Miriam advances to another stage in her pilgrimage, sampling the fare North London taste has dictated. From Rose Nouchette Carey's 'domestic' novels, she launches into Mrs. Humphrey Ward's world of Iuxurious society; then, finally exasperated and tired of the "mocking happy books," she reaches down to a lower, almost-out-of-sight shelf and. daringly draws out Under Two Flags.

This may be an ironic commentary by Dorothy Kichardson on the reading material of the solidly respectable bourgeois 
patrons. Catering: to a rapidly growing generation of women readers in the rising industrial society, the lending library conspicuously places on its upper shelves such novels as Rhoda Broughton's Cometh Up As A Blower (1867) and Charlotte Yonge's the Heir of Redclyffe (1853), dealing witl current moral, religious and domestic ideals; books that one can select and read unblushingly. But tucked away, down on the lower shelf, are the red-bound books by Louise de la hamee, known to the literary world as ouida, who rebelling against current ethics, wrote flamboyantly of splendid virile heroes, devastatingly attractive to female readers, and poetically portrayed such tragic heroines as Cigarette in Under Iwo Flags and Musa in In Niaremma, with whom these readers would identify. Ihe library pays tribute to the ethics of the sober Puritan clientèle but recognizes and caters to their susceptibility to the lurid and the sensual.

Miriam has reached the stage where she plunges into a book for the vicarious enjoyment derived from it. Reading Rosa Nouchette Carey cosily at home Miriam has envisaged herself happily espoused to some adoring man, growing old gracefully with him. Now a more mature Miriam, conscious of her stirring emotions, is desperately aware of others in the book, "those awful, awful women," with whom Miriam identifies, seeing herself irrevocably lost, and well-deserving her bleak existence at vordsworth House. She, too, is a "bad unsimple woman (I, 284)." 
Mrs. Hungerford's books seem the answer to the things liiriam seeks, they are an "escape" to a happier atmosphere, their deep emotional tone bringing to the surface longings hitherto only suspected. In them she is given a glimpse of gabled country houses, the sunlit twilit endless gardens, the deep orchards, the falling of dew, the mists of the summer evenings, masses of flowers in large roons with carved oaken furniture, wide staircases with huge stained windows throwing down strange patches of light on shallow thickly carpeted stairs $(I, 284-285)$.

This may be a foreshadowing of life at Newlands, and, maybe, a memory lingering from childhood when the ilendersons (and the Richardsons) enjoyed genteel luxury; the elusive something, more a state of mind than an actuality, that lured Firiam ever onward, as she sought.it in books, in music, in people, in religion, in herself.

As she reads, Miriam's days become an irrelevance and her evenings a dreamy self-indulgence. Finally, exasperated, she turns to Ouida. Miriam is beginning to move from books read in schoolroom days to more daring adult matter. It will be a devastating step to try Ouida, whose books she has been told are bad, evil books. Her books were all right for adults, Miriam knows, and Miriam feels more adult than anyone at Wordsworth House. Wiriam plunges even more deeply into Ouida's books, vicariously enjoying every sensual detail.

The strange currents which came whenever she was alone and at ease flowing to the tips of her fingers, seemed to flow into the book as she held it and to be met and satisfied. $[\cdot$. $]$ 
I want bad things--strong bad things. . .

It doesn't matter, Italy, the sky, bright hot

landscapes, things happening. I don't care

what people think or say, I am older than

anyone here in this house. I am myself $(I, 286)$.

Later she refers to books as a drug.

It is not until Miss Dear comments on Charlotte Bronte's Vilette that Miriam is jolted into recognizing why she reads those books. "It is a pretty book?" asks liiss Dear, Miss Dear who refuses to acknowledge, even as she fights against it, the unprettiness of life, valiantly trying to rise above its ugliness and drabness, cheerfully holding onto those who cross her path in an effort to survive by her wits, in an ever-losing battle against tuberculosis.

It is a pretty book?

She didn't want to know. She was saying something else. . . How to mention it? Why say anything about it? But no one had ever asked. No one had known. 'l'his woman was the first. She, of all people, was causing the first time of speaking of it (II, 259).

Did Miss Dear too, find a book an escape, a means of experiencing life vicariously? there is sensual satisfaction in identifying with a character; then one's emotional problems can merge with those of the character and be resolved with his. Miss Dear hasn't had much time for "study"; she has always been too busy earning a living.

As Miriam reads, Miss Dear shares the enotion with her.

But something was happering, something was passing to and fro between them, behind the text; a conversation between them that the text, the calm quiet, grey that was the outer 
layer of the tumult, brought into being. If they should read on, the conversation would deepen. A glow ran through her at the thought (II, 260-261).

They are identifying together with the heroine, giving added significance to the book, a book that, more significantly still, daringly emphasizes the passionate nature of a woman.

What do others find in a book? litiriam wonders. the Rev. Taunton relies on recommendations from his friends for his choice of helpful books. So he sends Red Pottage to Miss Dear while he, Mimself, engages in Great Thoughts Prom Great Lives and Plato. Discussing Miss Dear with the Rev. Taunton, Miriam recognizes him as a scholar but feels that he, not liriam, should be responsible for lviss Dear. In one way Miriam's time is more valuable than his. While his reading, like that of most men, is merely a habit, Miriam's reading is a quest.

To what extent does the reader's taste influence the calibre of books offered the literary market, she asks; what does the professional class require in a book? Iending libraries are in the main guided by popular demand, and Mudie's, one of London's larger lending libraries that cater to solidly, respectable, bourgeois patrons, among them Wrs. Orly, the dentist's wife, is no exception to this rule. Miss Orly's carelessly kept library list, as Mliriam reviews it, is not too stimulating. Mrs. Orly likes "something nice," "historical perhaps" though she has read a book by "that awful "Zola" and regards French frankness as "sheer bestiality." 
Wiriam, who has read Zola in French, cannot agree. Mr. Hancock concentrates mainly on dental magazines while Mr. Leyton reads the newspapers.

Modern, emancipated Mag and Jan, whose bookshelves are crowded with books, also borrow the latest publications from Mudie's. Hag selects books, not for the title and binding but for the books' own sakes, judging and comparing them with books by the same author; yet all this wonderful knowledge, Niriam observes, makes her seem wistful and regretful, "wistful hero-worship . . raving about certain writers as if she did not know they were people." Miriam finds Mag reading Children of the Mist by the regional writer, Eden Phillpotts. A wonderful book, ilag declares, Phillpotts gets all the atmosphere of the West; she lives there while reading him. One wonders if there is intended irony here; Mag in her snue, comfortable room wishing to live on a bleak Devonshire coast. Or is Dorothy Richardson trying to point out that we seek in a book a way of life that takes us away from daily routine, no matter how cosy it may be and no matter what our stated aims? Dorothy Richardson and her husband, Alen Odle, migrated regularly from their Cornwall cottage to their apartment in St. Joln's Hood.

High society, as represented by Mrs. Corrie, will have a negligible effect upon literary aesthetics, Dorothy Richardson seems to imply, if Mrs. Corrie's literary development can be judged by the empty sounding "stiboo-stibee" she sings with 
the children, or her excitement over Mèlee's "planchette" with its mediumistic messages.

It is an awful thing. It whirls about and writes with a pencil. Writes. All sorts of things, [. . Jnames. Anythin'. Whatever you're thinking about ( $I, 356)$.

Dorothy Richardson seems to be indulging in irony here, at the expense of the average writer.

In the literary atmosphere of Alma and Hypo Wilson's home there is a chill coldness to the books: The white Boat, King Chance, lirg. Pendergast's Palings; the chill of the strange sentences inside like a sort of code written for people who understand, written at something. They are, Miriam decides, like clever raised voices in a cold world. None of them are about ordinary people; nothing in any of them is about anything she knows or feels; there is nothing with which she can successfullyidentify (II, III). Her mental hunger still unappeased, Miriam resumes her quest. Having gorged on North London middle-class fare, grazed in viudie's more cosmopolitan field, nibbled on the ultra-modern only to reject it as being too exotic for her, as yet, undeveloped taste, she turns her attention to the masters in literature. Her opportunity comes while attending a performance of Hamlet to inquire into the reason for Shakespeare's greatness. Wherein did the greatness of Shakespeare lie? Mirian wonders. It is not in the acting because the actors miss it; they act at the audience, taking 
their cues too quickly, forcing their emotions to come too abruptly and then only from the surface not the inside. The characters in the story are tiresome, and the ideas--the wonderful quotations--if looked at closely are simply everyone's ideas. It is the sound of Shakespeare, lijiriam decides, the poetry, that makes Shakespeare real, like the music of Beethoven. Bad playing cannot destroy Beethoven, nor can bad acting spoil Shakespeare.

Shakespeare's true genius, Miriam feels, is revealed in The Merchant of Venice when he makes her sympathize, almost againgt her will, with Shylock, and makes her realize that she does sympathize. Portia was right when she preached her sermorl; it made everyone feel sorry for all harshness, but she wanted merely to save Antonio, doing that by abusing the letter of the law. The play should have ended there, Miriam thinks, with Portia pleading her case. Then she should have gone through all the law courts of the world, using her woman's wit to show up the law, for a woman's knowledge is "larger, bigger, deeper, less wordy and clever" than one of a man. Miriam condemns Portia's complacency about being unkind to a Jew, but then Portia has been invented by a man. There is no reality in Shakespeare's women; they please men because they show women as men see them. All the other things are invisible; nothing but their thoughts about men and brothers! The intimate woman-to-woman words and actions of Nerissa and Portia could neither be grasped nor created by 
Shakespeare. Miriam's thoughts race on as she leans against the barrier in the Iyceum pit. Shakespeare's plays are "universal" because they are about the things everybody knows; they make everybody feel wise. It is not what Shakespeare says, however, but his way of saying the things that don't matter, things that leave everything out. It is all a sublime fusg. With a few deft strokes shakespeare has been docketed. Despite his universality, Miriam thinks he has missed the essential something (II, 186-187). One significant point seems to have been overlooked however. Portia's speech which so captivated Miriam was not the product of "woman's wit" but was written by the man who created all the women characters, Shakespeare. Was it entirely Shakespeare's genius that worked a feeling of sympathy for Shylock, one wonders? Dorothy Richardson was known to be deeply sympathetic towards Jews, one of her closest friends being a Jew, Benjamin Grad, while Miriam has been aware of Jews since her brief romantic moment with Max Sonneheim when she was seventeen. These influences may have made Dorothy Richardson more aware of Shakespeare's clever handling of his characters. Shakespeare makes one aware of one's awareness.

It has been a discouraging pilgrimage thus far. Finally, there is nothing to turn to; books are poisoned (II, 222). Dorothy Richardson seems to take the reader only so far on the survey of books, then pauses for effect, permitting the reader to draw his own conclusions while Miriam expresses 
an opinion. Ihus on a bleak New Year's Tve we find Miriam sweeping her eye across the path she has so painstakingly followed. Still there persists the same dissatisfaction, the same nagging, frustration. Disillusioned, she makes her New Year's resolution: there will be no more books, for they all lead to the same thing. All the things in books are unfulfilled duty (II, 32I).

From Dante Miriam learns that love does exist. It is neither myth nor dogma but an actual, practical force that can move the spheres and inform the mind. Dante believes in a loving God who requires that man should be loving, too. It is as simple and as difficult as that. Out of the centuries Dante seems to speak to Miriam as to a friend $(I I, 354)$.

Inevitably liiriam must find her way to Ibsen, whose heroines set new standards of freedom for women. Every line of Ibsen is wonderful, yet not quite clear. Miriam keeps hoping on some turned page to find something that shines out and makes a meaning. She cannot understand Ibsen's genius or see where it is; but a book by a genius is alive. Ibsen is superior to novels because it does more than tell about people or their thoughts; Ibsen takes the reader somewhere to stey, forgetful of everything until it is finished. The genius of Ibsen for Miriam, and Dorothy lichardson, lies in its power to transport the reader beyond the present and the actual to some region Ibsen inaicates. "Yeople go around

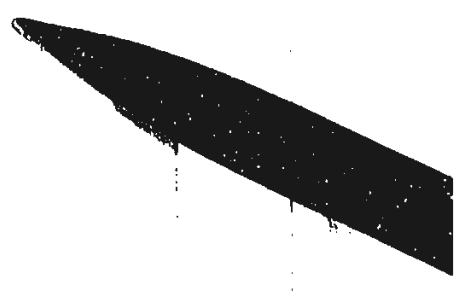


saying 'Ibsen's Brand' as if it were the answer to something";

that is not the secret of his genius, Miriam declares;

"Ibsen knows no more than anyone else (II, 382-384)."

Rather timorously Miriam has taken on the chore of tutoring in English the Russian student Michael Shatov, who introduces to Miriam the best Russian authors: Tolstoy, who, liichael says, "has a profound knowledge of human psychology;" and Turgenoev, more academical but cynical and satirical. Then he can't reveal anything, liiriam claims, dismissing satire as a waste of time, and condeming novels as an endless fuss about nothing (III, 45). In his slow llussian accent Michael disagrees, "it is not in general true that in fictional representation there is no actuality (III, 46)." Here, Dorothy Richardson seems to be stating briefly earlier criticism of the novel, giving both views.

Tolstoy's Anna Karennina, Miriam realizes, is a story of a woman, told by a man with a man's ideas about people. But the strange abrupt words--the conversations--are different from any Miriam has read before. What is the mysterious difference? There is in this book, Michael explains, a kind of "self-history of Tolstoy." It is a most masterly study of a certain kind of woman. Miriam's questing mind wonders why a book must be a masterly study of some simple thing. One may never find out what the book is about; that would mean being ignorant, having a kind of hopeless personal ignorance and unintelligence, only finding out by

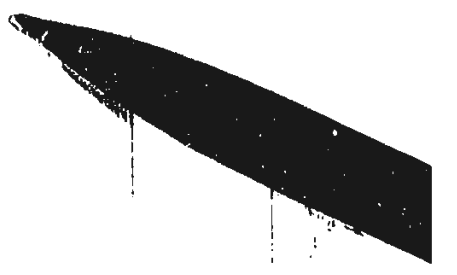


accident what books are about, even reading them again and discovering other things (III, 6I). Should a book be one specific thing, Dorothy Kichardson seems to ask, or should it not be a flow of many things from which the reader can select those pertinent to his individual interests? Dorothy Richardson seems to be producing such a book in her novel Piligrimage.

Michael forces Miriain to think, and through him Dorothy Richardson can promote the development of Miriam, giving us in addition an appraisal of another type of book. How does one find books? Hiriam once asked. Michael may be one means of solving that problem for her, she thinks. He brings piriam books with special meanings everyone understands. They seem real at the beginning, but they go off into things and do not come back. Niriam cannot understand them. After reading Emerson she can no longer enjoy novels; they show only one side of people, the outside. Meanwhile she decides that Michael must read Imerson, one English writer who knows everything, whose language is the purest and most beautiful.

In discussing the works of indreyev, the "mournful humanist," who believed that "in literary works there should be little room for words and large space for ideas, "4 Miriam tries to pinpoint the flaws in all writing. Here again, Dorothy Richardson uses Wirlam and Michael Shatov to give both sides of an argument on the novel, with liriam-or Dorothy Richardson--having the final expression of opinion. 
Life is not pathetic, Miriam insists, at least not altogether pathetic, all the time. In his slow careful English Nichael replies, "Simplicity and direction of feeling does not necessarily indicate a less highly organized psychological temperament (III, 146)." But Miriam accuses Andreyev of artistic exaggeration in presenting the pathos of the little boys and the man with the Chinese mask. She believes that

People don't feel pathetic; or never altogether pathetic. There is something else; that's the worst of novels, something that has to be left out. Tragedy; curtain. But there never is a curtain and, even if there were, the astounding thing is that there is anything to let down a curtain on; so astounding that you can't feel really, completely, things like "happiness" and "tragedy"; they are both the same, a half-statement. Everybody is the same really, inside, under all circumstances. there's a dead level of astounding . . something (III, 146 ).

The author should not overload his work with pathos nor tell the reader how to feel. Nirian has come a long way since first she cast a half-regretful look at her bookcase and scurried off to Hanover. She now casts an avid eye on the contents of a book. Adopting the role of critic, she challenges the author-critic Hypo Wilson himself, finding him guilty of a similar fault. He should cut out the pathos, she tells him, pointing to a certain passage; he weakens the whole argument by coming forward as the intrusive author to tell his reader, in those three words, what to think. In the moment that the reader turns away, everything goes, and he comes back distracted and different (III, 25I). In

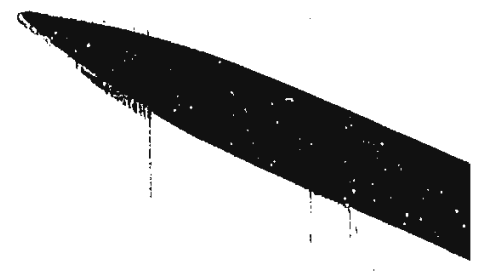


telling him what to think, the author frequently loses his reader. If the author himself feels the pathos, and Hypo did not, he will convince his reader without being dictatorial (III, 251-252)。

This point brings Dorothy Richardson round to her original quarrel with the novel--the male author himself. She tries through Miriam to explain the appeal, in spite of their flaws, of books by men. It is simply this, she decides: men write so well it is a relief to read their large superficial statements. There is a comfortable stretching of the mind in following the orderly scheme of things falling into place; a flattering fascination in grasping and elaborating the scheme, but in reflecting upon the book later, one feels only the poisoning gloom over everything. Miriam reflects that this gloom adheres to all sood writing, yet not to Dickens; does that mean that the people are right who say Dickens is not a good writer?

Conrad, she says, is a modern and a good writer; reading him is not like reading a book at all. One expects some difficult, mannish way of writing, but reading Conrad causes one to forget the grilling demands of a busy day, and to emerge refreshed and strengthened. People leave life so small it seems worthless, but Conrad leaves everything big; and everything read in Conrad can be added to experience for ever. Even God would enjoy reading Typhoon, Miriam feels. Conrad's characters are not made, not created, not begotten, 
but proceeding and working their salvation. Then without change of pace Dorothy Kichardson sweeps us along to this thought of Miriam's:

In the day of judgment, though he is a writer, he will be absolved. Those he redeemed will be there to shout for him. But he will still have to go through purgatory; or be born again as a woman. Why come forward suddenly, in the midst of the story, to say they live far from reality (III, 276)?

Is her tongue turned slightly towards her cheek? one wonders. Conrad, too, is guilty of the fatal flaw, intruding in a sudden smooth complacent male voice, detracting one's attention from the live text and directing it toward an image of a supercilious lounging form, complete with slippers and a pipe, while other men sit round. Why, Miriam asks in exasperation, cannot men exist without thinking themselves all there is?

Not until "The Irap," the last 'chapter' in Volume III does Dorothy Richardson lead Mirlam to the one book that, because of its fascinating technique of presenting the story through the consciousness of a character, is to become immediately the centre of Miriam's life. It is Henry James' The Ambassadors, a book that she has discovered in a little bookshop, drawn to it despite the neutrality of its title and of the author's name.

As she eagerly reads the book, Miriam's feelings fluctuate, on the one hand thinking it perhaps ridiculous to have been so excited by the way James conveys information 
without coming forward to announce it; on the other desiring to confront the author with his own cynicism, letting him know that in every word he comes forward with his views wich, in Iiriam's opinion, were the most hopelessly complacent masculine ignorance.

This man was a monstrous unilluminated pride. ind joy in him was a mark of the same corruption. Pride in discovering the secrets of his technique. Pride in watching it labour with the development of the story (III, 409).

There is a streak of blind pride in James-and in all who admire him--concentrating on his new technique while everywhere there are unmistakable signs of all that is left out. But the ignorance of James is unconscious, liriam thinks, and therefore innocent. And it is he, after all, who has "achieved the first completely satisfactory way of writing the novel," something to make, like Conrad's work, the heavens rejoice. If this is a novel there is something holy about it, but the book can not quite accomplish the task required of the novel. These potent words leave a bitterness in the throat, bringing as they do a sense of the guls between life and the expression of it. Miriam has reached the conclusion that fiction is at worst a highly flavoured drug and at best as much an abstraction as metaphysics (III, 426).

The torment of all novels, Miriam mourns, is what is left out. Whe people in James know so much and yet they do

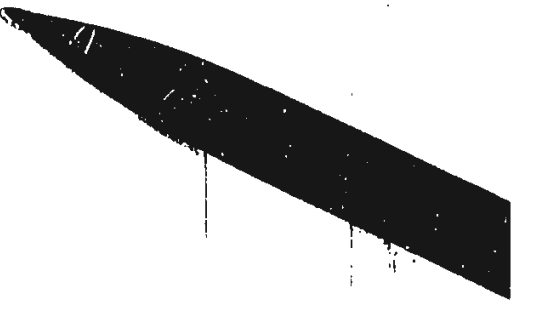


not know. Miriam is distracted from utter joy to fury over a.l James-and Conrad--is unaware of, over the self-satisfied, complacent, know-all condescerdingness of their handing of their material. H.G. Wells, she muses, seems to have some awareness, but all his books are witty explorations of ideas. Bang, bang, bang, on they go these men's books, like an I.C.C. tran, yet unable to make you forget them, the authors, for a moment

(IV, 239).

Miriam worries over these novels, yet she is always thrilled to hear of a new author, and pauses in her lament to comment on Arnold Bennett, who could make ordinary life seem so extraordinary. The way in which he blends the real with the fantastic in his social history novel clayhanger (1910) has special appeal for Miriam and, no doubt, for Dorothy Richardson. "Bennett," Hypo tells Miriam, "is a reslist. Documenting." A lifetime, Miriam thirks, might be well spent in annotating the male novelists: filling out the vast oblivions in them, especially in the painfully comic or the painfully tragic and in the satirists.

Miriam has spent years listening to Iypo expound his theories on works of literary art, learning to regard these works through the professional eye of the critic. Ironically, she now has a clearer conception of Hypo Wilson's work. She has reached the stage in her own literary development when she can clearly and concisely enunciate her estimate of his work. 6 
For although from time to time, under the spell of his writing, she felt that from him alone was coming a clear, vital statement of mankind's immediate affairs and that all human activities should cease while he had his say, she was haunted, even in the midst of the miracles of illumination worked by the theories guiding his perceptions, by the insufficiency of these theories to encompass reality; and found herself growing [: $\dot{0}]$ increasingly impatient of the scientific metaphors tyrannizing unquestioned wit
much of his statement (IV, 360-361).

No one else, considering the human spectacle, saw so clearly as he and in so many directions or on so large a scale what was going on. No one else had a sreater measure of intellectual force and brilliance of the nodern world and called it Anti-Christ. Chesterton believed that clear thought was incomplete thought. [i. ] Beginning nowhere it ended in a void $(\mathrm{IV}, 362)$.

Dorothy Richardson, perhaps, is sounding a note of warning here cautioning the reader not to be too easily persuaded by Hypo's--and Wells'--sweeping affirmation. His scientific handling of social problems, his rapid judgments, his quick impatience with ideas other than his own, give Dorothy Richardson some cause for concern.

In Miriam's literary pilgrimage thus far, Dorothy Richardson has touched upon some outstanding characteristicor lack of one--in the books examined by Miriam: the frivolity of the novel advocated for the sheer entertainment of young lady readers; the daring of charlotte Brontë's Vilette in being one of the first to present woman as equally passionate with man; the striking point-of-view of James' The Ambassadors; the genius of Ibsen in transporting 
his readers so successfully into another world; the majestic material and style of Conrad's Iyphoon; the inadequate portrayal of women by Shakespeare; the fantastic realism of Arnold Bennett; the scientific flavour of Wells books. All these points were pertinent to the period Dorothy Richardson is documenting, and, no doubt, had even more significance for her readers at that time than they would have today. laking advantage of a much needed holiday at Dimple Hill, Miriam next moves on to a study of the influential thinkers of the world, those to whom great nations are indebted for inspiration, for ideas on freedom and brotherhood. High on the list stands Henry Thomas Buckle (1821-1862), the first to write a thoughtful and perceptive history of civilization, influential in creating revolutionaries in Russia by showing that only in those countries which have escaped from religious and political despotism has civilization been able to develop. Buckle's History of Civilization was a gigantic introduction to what was to have been a detailed comparative discussion of the countries of the world. Dorothy Richardson leaves one wondering how great would have been his influence, had he finished the work.

Of particular interest to Hiriam and Dorothy Richardson as one of the founders of the first suffragette society, is John Stuart Mill (1806-1873), whose Subjection of Women, (1801)--presumably referred to by Dorothy Richardson when she speaks of The Influence of lomen--proclaims women as the 
sustainers and preservers of inductive reasoning. Miriam next selects l'olstoy (1828-1910), "shedding darkness as well as light"; Tolstoy's literary works seek to reveal the workings of the inner being, to verbalize the semi-articulate processes of the consciousness and reveal the conflict between unreflecting nature and right reason, the outcome tending usually towards naturalism and the noble savage. When Turgenev (1818-1883), whose women characters, stronger and more attractive than men, are drawn against a subtly-woven poetic atmosphere. Miriam envisions him as sad, shadowed sunlight; perfection, but enclosed, as all great writers seem to be, in a world of people, related only to each other. He seems to be presenting human drama in a resounding box, or under a silent sky. Finally Dostoievski (1821-1881), at first humanitarian idealist, then tragic creator, famous alike Ior the imaginative and dramatic qualities of his work as well as for his realistic characterization. Of the latter Iririam says, Dostoievski does not judge his characters; whatever and wherever they are, one feels in and about them the presence of an irradiating light (IV, 4I6).?

Dorothy Richardson has shown us that these authors, of singular importance to Russia, are regarded in a slightly different light by Miriam, an indirect comment, no doubt, on the variability of what is sought, and sometimes found, by the reader in books.

Recalling her thoughts from Kussia, and in the light of 
what she has already read, Miriam very carefully considers Emerson who "saw everything--saw life steadily and saw it whole." Iife in Emerson's day stood still enough to be looked at by the author, comfortably seated in a solidly upholstered armchair. "All your Mrnolds and Emersons and Carlyles," says Hypo, "prominent men in a stagnant old world had no end of a show . . a few figures enthroned and impregnable; voicing profundities (IV, 417)." Miriam suddenly sees Emerson, with a private income and a mystical consciousness, unperturbed over commerce or the market-place, setting down crystalizations of his thoughts the moment they appear until there stands ready to hand the materials of his essays. And here we are given the first little hint of criticism: perhaps that accounts for the feeling of nostalgia one has for an essential something missing from his work. Almost unknowingly Miriam is becoming more aware of Emerson's weakness. Though she admires his control of language, his increased power of contrasting adjectives, "Home--so odious and so dear," he is not now the ultimate in writing that once she considered him; she is conscious of a sense of dissatisfaction. Finally Amabel voices it, "We find Emerson trite." Emergon is luminous, amiable, reasonable, humanistic-incomplete. Again Amabel speaks, "Mike has done with Fmerson. We both find him trite (IV, 545)." Iooking back at Imerson for the first time fully in the face Miriam realizes that Amabel means: Imerson's scholarly urbanity 
perpetually checked his poetic insight, keeping within decorous bounds what, unleashed, might have reached out in ecstasy

By a strange coincidence Wichael has come into Miriam's life at a time when her interest has been aroused in philosophy, "the strange nameless thread in the bocks that were novels (III, 18)." Miriam realizes she cannot keep pace with Michael but she may learn something from him before he terminates the lessons. Forcing her to look at books with the universal eye of the scholar, to see, to discuss, he has opened a new world to Miriam, while her growing interest in philosophy has been given added impetus when she attends a lecture by the famous philosopher, McTaggart, but soon she discovers that philosophy is not what she seeks. Philosophy, she realizes, is not difficult; it is common sense systemized and clarified. It is not what people think but what they know that is important. "Whought is words, but philosophy will never find words to express life; actually the philosopher is the same as the criminal (III, 173)." But Miriam doesn't tell us now.

The process of expressing thought, of presenting the Truth, must be considered in any literary work. All that has been said or known in the world, Miriam muses, is in language, in words, but one ought not to think in words, one should think in one's brain. All we know of christ is in Jewish words; all the dogmas of religion are in words, whose 
meanings change with people's thoughts. Then no one knows anything for certain; everything depends on the way a thing is put, and language which is continually changing is the only way of expressing anything. Dorothy Richardson makes a rather frightening statement: culture comes through literature, which is only half-truth (II, 99). Miriam has progressed another step in her quest; she not only seeks the philosophical meaning in a book, but the meaning behind the meaning of the words.

perhaps the thing Miriam seeks is not to be found in any one book; the answer may lie in meeting the author of his words, face to face, at a lecture; the answer way be found in science. Attending a lecture at the Royal Institution with Mr. Hancock Miriam thinks

To begin again... but now not only books. [- .] but the latest newest things from the men themselves--there would be an audience, and $a$ happy man with a lit face talking about things he had just found out. Even if one did not understand there would be that. [. - it was an education . . a liberal education (II, 101).

But instead of happy excitement over the wonderful discoveries Hiriam finds a kind of deadness to the people who frequent the place, "with their gentle enlightened faces and their keen enlightened faces" (II, 102) that set them apart from worlaly people. they wear an air of culture and refinement but they are never really aware of anything behind or around them because of the wonders of science. 
Miriam leaves the enlightened souls to their science and returns to books. With a sense of shock almost physical in its intensity, she discovers while reading "a black and twisted, painful tragedy" that she is the one who really reads a book, others do not; she reads to find the author, her reading is a psychological study of the author. Through books she will learn to know people, not the characters in the stories, but the authors; and the world is full of books, she gloats. In life everything is scrappy and mixed up (does this explain Pilgrimage?); in a book the author is there in every word. 8

Consequently Wiriam is conscious of an added thrill on receiving and opening a new book. Invariably during the course of the first half page the author, self-described in his turn of phase and use of epithet and metaphor, makes his appearance, and so busy is she tracing his portrait that she forgets the underlying meaning, and leaves his produce to be inferred. 9

Whether the reader has been aware of it or not, Dorothy lichardson has carefully examined for his benefit every aspect of a book, beginning with its physical appearance, binding, lettering, illustrations, and discussing its title, before moving on to its content, which includes a single plot for light entertainment; then something more complex, more exciting and sensual with which the reader can identify; finally the deeper philosophical thought of the author.

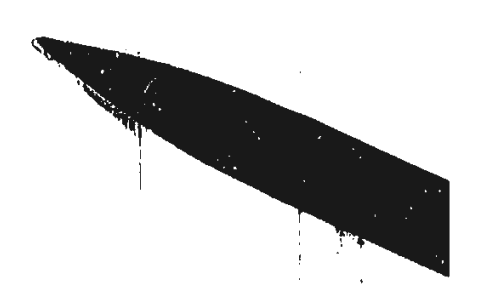


Setting, atmosphere, diction, point-of-view have been discussed, then style, leading to the author himself. In each case Dorothy Richardson has selected some book or books where emphasis has been placed on the point under discussion. Thus we have James for point-of-view, Philpotts for setting; Ouida and Brontë for sensual plot; Conrad for character, to name a few. In addition she has discussed light and more serious fiction, poetry, drama, philosophy, as well as historical, scientific and social novels.

\section{II}

Miriam, always conscious of the need to converse or to maintain a conversation, catches with a very sensitive ear the inflections and cadences of the human voice as well as the accents, foreign and cologuial, of those with whom she converses. Miriam thus displays a growing facility with another of the language arts, the subtle ability to convey through direct speech the character and mood of the speaker. Dorothy Richardson cleverly and persistently pursues this practice through pilgrimage, and as Miriam captures, registers and mimics the speech of those within earshot, so we, without explanation from the author, can find our comprehension of the speaker's character greatly enhanced.

Sisterly conversation can reveal much. Having just returmed from an interview with the Misses Perne at Wordsworth House for which she has just been appointed resident teacher, Miriam walks in on Harriet making preparations for saturday 
niwht's dance.

'What you doing, booby?'

'Old conservatory,' panted Harriet.

'Well goodby?'

Miriam grinned.

'You've got j.t. [. . . ]'

'Oh yes, I've got it,' smiled Miriam

'But don't let's talk aoout that. [0.]

I've got three bally, blooming weeks.'

[i. : : $]$,

'What about Saturday?'

'It's all right. I'ed was at the club.'

'Was he!'

'Yes, old scarlet face he were.'

'I'm not' ( $I, 201)$.

the Wordsworth House girls also discuss a party. Their

slang is unsentimental, forthright, and vulgar.

'Koo, isn't it a filthy day!'

[:. ]'What's the bally row? [. . ] Whet's

the bally shindy beloved?

'Nothing. Wait for ine. That's all.

' Oh, my lungs, bones and et cetera.

It's old age, I suppose, Uncle William.'

'Well, hurry your old age up, that's all.

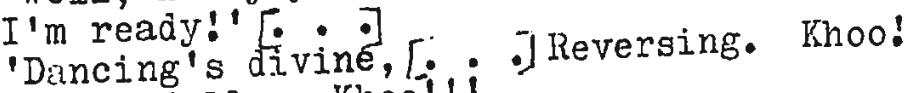

with a fella. Khoo!!' You do indeed.

Hoh. Shocking.' What do you mean, Poll?'

'Shocking? Why? What do you mean, (I, 250-251).

Mthough Miriam and her sisters had used slang there was a noticeable difference in tone.

While dining with Hypo and Alma, Miriam gives Hypo a lesson in phonetics, showing that people articulate as they do because of the evolution of vowel sounds under social duress. She illustrates her point: 
Say, being careful to speak slowly, 'Too many irons in the rire.' [. . . I ivery one, [. * : $]$ excepting most of the people here and their like, suffer, when they say those words seven separate, face-distorting convulsions (IV, 161).

'Pooo, men-ny, eye-erns, in, the fy-er.' [A ccenting the stressed words.] Incessant chinwagging. Jaws moving round like grindstones. 'Toom-ny ahns in 'th' fah.' Just two small snaps. [. . ] The only people who retain the native hideousness of the English ' $i$ ' and ' $a$ ' are the cultured middle classes, academics, and all who don't care what happens to their faces when they speak as long as their speech is what they imagine to be correct (IV, 162-163).

Middle class jargon, Miriam continues, is mincing, from a genteel aspiration to keep the mouth closed. Lower class variations originate in hearty revelling in sound, especially in open-mouthed vowels. "Speech is an Englishman's only gesture. Hence its heavy accentuation (IV, 164)."

Speech derives from a technique in dealing with people, and is "born of a spiritual conaition." $\dot{A}$ school prefect, wishing to maintain dignity, will "avoid all sounds that tend to discompose[his] authoritative and dignified mug." In the diplomatic service, where graciousness and bonhomie are as important as dignified composure and authority not especially called for there is less jargon and more face-convulsion (IV, 165).

People who speak beautifully, like those who have beautiful handwriting, are usually either humbugs or charlatans. 
Dorothy Richardson makes one aware of the oddest points in phonetics; for example with Egypt she points out, "neither the sound nor the sight of the word was lovely. $[\bullet \cdot]$ The opening sound uglier even than 'cheese,' the pouting spit of the conclusion: hopeless (IV, 216)."

of her niece Elspeth, Miriam comments, "I tried writing her after she began to go to school. In her answer, in pure American, she wrote elevator in two words: 'ella vater,' and the shock of hearing her speak American, and of realizing she would grow into an American girl, prevented my writing again (IV, 309)."

Miriam is conscious of the need to maintain a conversation or, conversely, to relax into a tranquil silence, as the (iuakers do (IV, 472-473)。

Possessing an ear sensitive to inflections, cadences, colloquialisms, affectations and other mannerisms of speech, Dorothy Richardson was blessed with the couplimentary gift of being able to translate a mannerism to the writer's word so accurately as to make it audible to the reader. Lven on her first evening at Waldstrasse "it gratified her to discover that she could, at the end of this one day, understand or at the worst gather the drift of, all she had heard, both German and lirench. $[\cdot$. ] She must have a very good ear $(I, 47) . "$

At the Corries' dinner table she 'umpires' the argument over the pronunciation of Bologne. Carefully enunciating the

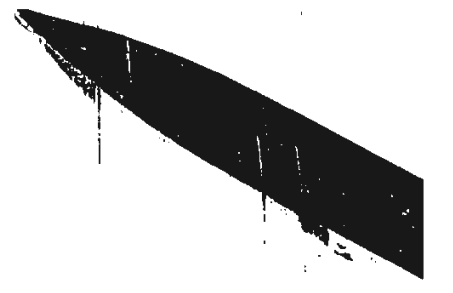


word. What did it matter, after all, the richt pronunciation? It did matter, not that "Bolone" was wrong, but the awrulness of being able to miss the right sound if you had once heard it spoken $(I, 378)$ !

A neighbourly chore (III, 131-133) undertaken to help

a fellow boarder and a foreigner gives liriam cause to examine critically the mechanics of the spoken address, and in doing so opens her eyes to the mechanics of writing. This, with a nudge from Michael Shatov, stimulates her to undertake serious writing, a step undoubtedly leading to her eventual attempt to write the 'perfect novel.'

Mr. Lahitte, a French boarder at Mirs. Bailey's, is engaged to give in English a lecture on Spanish literature, and, recognizing certain obvious difficulties, asks ifiriam to review his speech and indicate not so much its flaws as the intonations he should adopt in reading it.

Mentally listening to the speech as she quickly scans it, Miriam is amazed to find herself waiting for something which does not arrive; the speech is empty of everything but superlatives leading nowhere, and is merely a verbal trap from which the audience cannot escape. The tone is all wrong. Mr. Lahitte seems to shout at his audience-and the sentence structure is too involved. Realizing the impossibility of trying to salvage the speech, Miriam yet prepares notes applicable to the preparation of speeches in particular, but also to written work in general.

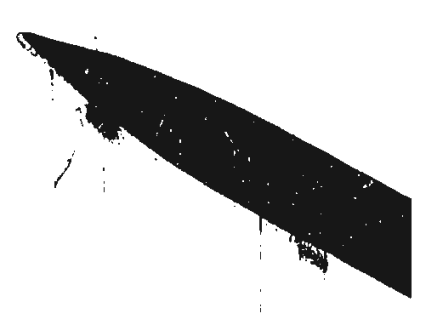


Ereak up long involved sentences, she suggests; the attention of the listener vill break under the strain of following its many involutions and digressions. Yet there is, we should like to point out, a place for the long sentence (in written work, at least) in presenting explanations or philosophic ideas, while short sentence fragments frequently contribute to monotony and obscurity. It may very well have been Dorothy Richardson's too-continuous use of phrases and fragments that gave rise to accusations of obscurity in her earlier work, although, in many cases, with surprising success, she has verbalized partially-conceived thought at a pre-speech level. 10 on the other hand the lengthy periodic sentences of her later style--as we shall see--carry the writer on a long involved journey before he reaches his destination. "The sentences grew in length, each one climbing, through a host of dependent clauses (III, 116)," might very well have been said of Dorothy Richardson's style. Use participles instead of "which," Miriam continues. The substitution of participle phrases for slower moving clauses gives a feeling of motion to thought, particularly helpful in stream-of-consciousness writing. Again, vary the adjectives to avoid monotony. Dorothy Richardson frequently uses adjectives in long unpunctuated strings. Leave gaps here and there, Miriam suggests, to give the listener or reader pause for nental review. (Don't browbeat him with a continual barrage of words). But an overuse of this may give 
an air of incoherence to a literary work--one of the criticisms directed toward Dorothy Richardson's Pilgrimage. Define the topic (in Lahitte's lecture the picaresque novel). But Dorothy Richardson, as a rule, leaves the mind of the reader to submerge itself into Miriam's mind and to grasp intuitively what is being thought and said. But when Dorothy Richardson does pause to describe, she can do so with poetic precision.

Introduce quotations, Miriam goes on. If well-handled, long and short alternated, they will give power and life to a speech. Dorothy Richardson does this indirectly in her novel, through Miriam's consciousness.

Mirlam advises Lahitte that he should (presumably in his discussion of characters in a novel) "Introduce their philosophy of life, if any (III, 132)." It may very well be that the character in an existential novel has no philosophy, except the philosophy of having no philosophy. A similar criticism has been made of liiriam. But Dorothy Richardson makes it clear from the outset that Miriam (and Dorothy Richardson) believes there is a hidden happiness or 'light' within all human beings, and it is the duty of each individual to himself, to seek this inner self, otherwise he remains half-created. A corollory to this theory is that one should also seek in others the real self hidden behind superficiality. Miriam gives a final word on style--avoid artificiality. For style, as Miriam discovers, when she re-reads her notes, 
is a portrait $j n$ words of the author himself. So--avoid the "ornate alias" (III, 133).

In formulating these rules, Niriam takes her first close look at a literary work from the point of view of the artist. Having picked up her pen she does not lay it down. we leave her, at the end of the book, deeply involved in a "Pilgrimage" of her own.

\section{III}

In her foreword to Fil wrimage, Dorothy kichardson makes rueful reference to her "unpunctuated" and therefore "unreadable" work. But she believes feminine prose "should properly be unpunctuated, moving from point to point without formal obstruction." Charles Dickens and James Joyce, she informs us, were well aware of this (I, 12). Dorothy Richardson confesses to deliberately ignoring minor punctuation marks and on occasion using more than was necessary, a practice which did not go unmarked and uncomplimented by her friends and her editor. She reminds us that an article ${ }^{11}$ she wrote explaining and justifying her style of punctuation had been included in a textbook on journalism and later translated into French.

Dorothy Richardson later regretted any obscurity her unique style of punctuation may have occasioned. In an interview with Vincent Brome in $1959,{ }^{12}$ she refers to this as a mistake. She felt later like apologizing to her readers, 
she tells Mr. Brome. A reputation for creating unnecessary difficulties is very difficult to live down.

But Dorothy Richarason's seemingly erratic and irregular punctuation is a very clever means of communication. In an atteint to surmount the difficulty of writing from one particular point of view while keeping the reader advised of events beyond the range of that single consciousness, Dorothy Richardson on one occasion uses the medium of a letter; Eve writes to tell Miriam of Harriet's ongagement and Bve's new job. As Miriam eagerly peruses the letter we follow her trend of thought, her immediate reaction to the news. We are given mere snatches of thought punctuated solely with dashes (with the exception of three periods). Hiriam's mind seems to underscore the highlights of the letter:

Very sweet and charming--my own young days-that I have reached the age of twenty-three-resident post in the country--two little girls-we think it very good pay--I shall go in September--plenty of time--that you should come home for the holjdays ( $I, 180$ ).

Apparently ive considers the romance of sixteen-year old llarriet very sweet and charming. It reminds her of her young days; Eve has reached the old age of twenty-three. Whe has accepted a post as governess to the young daughters of a well-to-do family living in the country, at an excellent salary, duties to begin in september. But there will be plenty of time to talk about that. Whe family thinks that Miriam should come home for the holidays, rather than 
accompany the school to Norderney.

On an earlier occasion when depicting Piriam's jumbled, tormented thoughts as she tries to settle down to sleep, Dorothy Richardson uses ellipses to indicate the movement of ili rian's thought:

Mir. Brough quoted Milton in a sermon and said he was a materialist. . . Pater said it was a bold thing to say. ... Mr. Brough was a clear-headed man. She couldn't imagine how he stayed in the church. ... She hoped he hated that sickening, jdiot humbug t've . . meek... with silly long hair . 'divinely smiling' . . Adam was like a German ... English too. ... Impudent bombastic creature . . a sort of man who would call his wife 'my dear.' I'here was a hymn that even pater liked... the tune was like a garden in the autumn...

0 ... Strength and Stay-up- . . lioldingall Cre-ay-ay-tion... Who ... ever Dost Thy ... self-un . . Moved-a-Bide. . . Thyself unmoved abide ... Thyself unmoved abide ... Unmoved abide.... Unmoved abide. $\because$ Unmoved Abide... (I, 170).

In the hymn Dorothy Kichardson uses capitill letters to indicate the beat, ellipses to mark the pauses, dashes to mark the elisions, and italics to set off a soaring note. The hymn sings itself.

liacing thoughts can also be conveyed by an alternation of semicolons and ellipses; semicolons being used to separate phrases that follow one another in natural sequence, ellipses to indicate longer breaks in thought:

Miriam marched angrily forward with shaking limbs that steadied themselves very quickly - . the nicht had become suddenly cold; bitter and penetrating; a north-east wind, 
of course. It was frightfully cold, after

the warm room; the squall was bleak and

endless; the many facades were too far off to keep the wind away; the pavement was very cold under her right foot; that was it; she could walk with it; it would not matter if the weather kept dry . . . an upright gait, hurrying quietly away across the moonlight sheen; just the one she had summoned up anger and courage to challenge, was not so bad as the others. . . they were not so bad; that was not it; it was the way they got in the way . . figures of men, dark, in dark clothes, presenting themselves, calling attention to themselves and the way they saw things, mean and suggestive, always just when things were loveliest. Couldn't the man see the look of the square and the moonlight? just when everything flashed out after the rain.. the sudden words close to her ear . . my beauty . . my sweet . - you sweet girl . . the pale puffy old face, the puffs under the sharp brown eyes. A strange . - conviction in the trembling old voice.. it was deliberate; a sort of statement; done on purpose, something chosen that would please most (II, 96-97).

As she walks home alone, late one moonlight night, Miriam is accosted by a strange man with a smiling face and a deprecating manner. So angry is she at the recurrence of this kind of incident that she snaps at the nan, causing him to turn and hurry away. Dorothy Richardson uses commas, semicolons and ellipses to show the direction of Miriam's thoughts as they slide from a sudden awareness of the cold, partly due, no doubt, to the unpleasant incident, then back to the retreating figure of the man, then farther back to a memory of a similar occurrence earlier in the year; she uses these punctuation marks also to show the tempo of Miriam's 
thoughts as they race angrily forward, pause, race angrily along again, then slow to quieter meditation.

Dorothy Richardson's apparently careless attitude towara inverted commas contributed in no small measure to the difficulty and obscurity of her style, as B. M. Haisel notes. 13 On one occasion she carefully encloses direct quotations, those of Miriam's and other speakers, in inverted commas; on another occasion she omits quotation marks. At one place 14 Hiriam's thoughts are narked by inverted commas; at another 15 Miriam's thoughts and other first person constructions are open, while sentences dealing with Mirian's own experience remain unenclosed. The difficulty multiplies when there is an abrupt shift from one form of punctuation to another.

l'o convey the ever-flowing stream of experience through Miriam's consciousness, Dorothy Richardson uses the present or the imperfect tense with the third person pronoun "she" or the first person "I." She uses present participles to

\section{link ideas.}

Not infrequently Dorothy Richardson repeats a noun, a verb, an adjective or an adverb to emphasize a point, to deepen an atmosphere or to reinforce a description. Thus we have repetitive adjectives, "a soft clear reed-like happy ring that Miriam felt to her knees while her happy feet stumbled on (II, 79)"; adverbs, too,"... disappeared softly into a softly lit room"; and verbs "making it show as it showed to her." On another occasion she uses a long 
string of unpunctuated monosyllabic adjectives, "Violent soft rich red and blue and dull green covering the huge concave dish from side to side (II, 50)."

In a stream-of-consciousness novel, the structure of a sentence can be used effectively to convey or express thought, frequently revealing at what level of consciousness that thought may hover:

It was a fool's errand. ... Po undertake to to go the German school and teach ... to be going there... with nothing to give (I, 29).

As Miriam nears her destination and her new teaching position in Germany, broken sentences indicate her distraught state of mind; the rhythm of the phrases echo the laboured beating of her heart. Igain, short staccato sentences in tune with ber frightened thoughts are interspersed with dashes and ellipses, the dashes uniting the thoughts, the ellipses separating them ( $I, 31)$.

Dorothy Richardson's style tends naturally towards the Imagistic. Every thought and description is designed to appeal to the senses, and all the senses are, at some time or another, brought into play--sight, sound, touch, taste and smell--as a highly sensitive Miriam responds fully to her environment. A striking example of imagistic writing is found in the Trap, Chapter VIII:

Another spring vanished. . .

A sheet of crocuses singing along the grass alley. White, under trees still bare. Crocuses dotting the open grass with June gold....

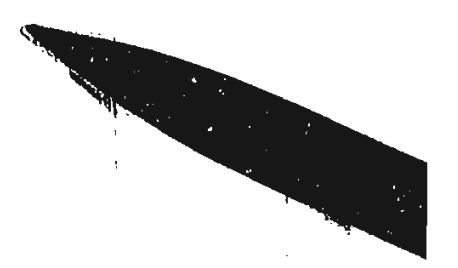


Suddenly a mist of green on the trees, as quiet as thought. Small leaves in broad daylight magic reality, silent as miday amidst the noise of traffic.

Then full spring for three days. Holding life still, when the dawn mists drew off the sea and the garden and revealed their colour (III, 498).

These are sentence fragments, almost incoherent, yet

exquisitely delicate in tone. A whole chapter has been

captured in a dozen lines of poetry.

Pilgrimage is brimming with poetic devices, onomatopoeic expressions such as "waves flumping " and Michael Shatov's "brumming," zeugmatic turns of phrase, "she ran upstairs narrowly ahead of her thoughts (IV, 118)"; oxymora, "careful carelessness," "shapeless shapeliness," "serenely tempestuous"; and alliteration where description is subordinate but necessary; concrete adjectives assuming force of metaphors. lhere is a strange use of personification when a whole dancing group seems to speak to

The dancing forms told her of the absurdity of going back without protest to the long aching days of teaching. . . " "Certificates-little conceited papers, and you dead. Certificates would finish you off--kill--kill--kill--kill $(I, 322) ! ! "$

They are advising her to resign from her position at Wordsworth House where her spirit is slowly being destroyed. So forceful is the spell of the dancers that Miriam mentally writes her resignation as she watches them circle and spin. More indicative of Dorothy ilichardson's later style are 
her lone periodic sentences with long involved interpolations:

l'hough revealed, by her flushed face and slightly dishevelled hair, as bondservant to the tedious indispensible mysteries, Miss Roscorla stood, as if permanently free and available, taking in the disposition of affairs, a little wistfully perhaps, being a sister and a sharer of the past rather than a wife and, therefore, to some extent, an alien; but also with pleasure, since she radiated a rich renewal of yesterday's intimate kindliness, standing still for a moment in the midst of her busy life with a uind 'at leisure from itself' and from the affairs that gave to her presence, though her eloquent dark eyes were free of the shadow of preoccupation common to the eyes of housekeepers, something of their odious power to disqualify and to drive away the masculine morning mood and to substitute, for its vast leisurely perspectives, the prospect of immediate activity, already, Miriam observed through the corner of her eyes as she stood responding to jiiss Roscorla's greetings and encuiries, embodied in the figure of the elder brother, bent forward to gain from the edge of the table, upon which still his hands were resting, purchase for his huge upheavel, and now, upon the would-be decisive 'well' of one aware he should have moved long since, risen to its full height (IV, 44ं).

Dorothy Richardson has written a single sentence of over two hundred words, consisting of interpolation within interpolation, while the thread of thought seems to follow Miriam's eye as it looks round, through and beyond the Roscorla brother and sister.

The striking rhythm of Dorothy Iichardson's style is cleverly contrived as she varies her methods. An emphatic initial clause falls gradually away with an appealing caderce; short staccato phrases are offset by long meditative passages,

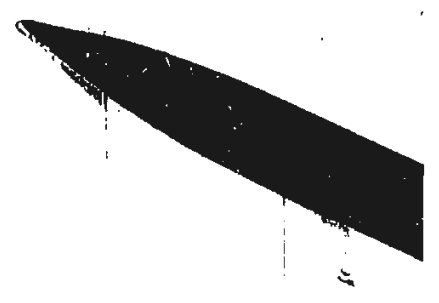


whilc repeated 'f's and 's's' weave a soothing, monotonous

spell round the unwary reader:

Homage and contempt for women come equally

forth from him, the manifest faces of his

fundamental ignorance. The feminine world

existed for him as something apart from life

as he knew it and to be kept apart (IV, 82).

With a puff from the alliterative 'f's' Miriam is aismissing

Vereker's friend, "evil Eaden."

In a few well-chosen words Dorothy Richardson can create

a desired effect. When Mirian departs from Hanover,

Fraulein Pffaf accompanies her to the station and Dorothy

Richardson adroitly captures the sensation of movement as

Miriam boards the train:

The platform was moving, the large bright

station moving away. Fraulein's wide smile

was creasing and caverning under her hat from

which the veil was thrown back. [. - :]

Fraulein's form flowed slowly away with the platform ( $I, 185$ ).

Dorothy Richardson creates a distinct impression of one

remainine static on a moving train while all else flows away.

But perhaps Dorothy Richardson's distinctive style can

best be exemplified by her description of the "haarwaschen"

at Waldstrasse:

Mirian's outraged head hung over the steaming basin--her hair spread round it-like a tent frilling out over the table.

For a moment she thought that the nausea which had seized her as she
surrendered would, the next instant, make flight imperative. Then her of an eggshell caught the sharp bump-crasin, followed by a

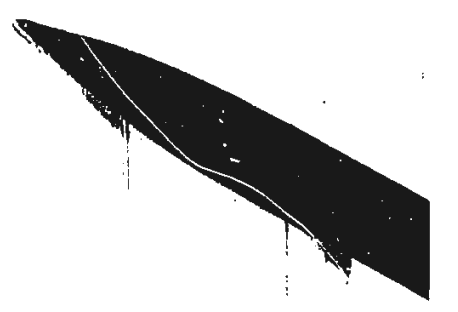


further brisk crackling just above her. She shuddered from head to foot as the egg descended with a cold slither upon her incredulous skull. Tears came to her eyes as she gave beneath the onslaught of two hugely enveloping vigorously drubbing hands-'sh-ham-poo' gasped her mind (I, 60-6I).

The onomatopoeia of "bump-crack," "slither" and "drubbing";

the bypallage of the "outraged head," "amazed eyes" and

"incredulous skull"; the apt smile "like a tent frilling

out over the table," emphasizing the pathetic predicament of the victim, has turned the rather mundane chore of hair-washing, into a poetic adventure.

Dorothy Richardson has elected to use imagery rather than symbolism to suggest private emotional values. Once recognized, the image can serve to identify a mood. Thus Miriam's involvement with sunlight, fresh air, trees, "a little garden," walking, rooms, walls, food, soap, ${ }^{16}$ warm water, tea, conversation, music, quiet warm friendships, though seemingly insignificant, is extremely important and is presented with precision without fulness. Jiy suggestion an atmosphere is created, one word, frequently, being the key to Miriam's mood.

Punctuation, phrasal units of thought, changes from third person to first as stream-of-consciousness becomes interior monologue; economy of words, images to create $a$ mood, and staccato rhythms of language as Miriam's mind leaps from thought to thought; these have been some of the tools used by Dorothy Richardson in creating Pilgrimage. 
Others may lay clain to similar tools, but these have been used here with a vigor, a precision and a sensibility unique to the hand that wielded them.

Jorothy Richardson's writing reveals an ear sensitive to sound, tone and inflection, as with matchless mimicry she records the accent of a sveaker, or sounds the beat of a hymn, the tempo of a poem. As Miriam so aptly remarks, there is a sort of spiritual metronome at work, imperceptible except when something goes wrong. It operates, too, upon sentences, a syllable too few or too many brings a feeling of discomfort forcing one to make an alteration. Perhaps, sine thinks, there is a definite thought rhythm and speech rhythm that cannot be violated without producing self-consciousness or discomfort (IV, 352).

Style, says Dorothy Richardson, is somrthing beyond good and evil; it is something sacred and innocent (III, 410 ). Dorothy Richardson's style was the direct result of the task she had set herself in writing a psychological novel, but it was also a reflection of herself, her individual mode of expression. For style, says Dorothy Richardson, is a signed self-portrait.

\section{IV}

Running parallel with Virian's development as a reader and attaining increasing importance as Pilirimage progresses is a treatise on the art of writing in general, leading up 
to and culminating in the creation of the ideal novel.

It might be rewarding to view a book from behind the scenes, Dorothy Richardson seems to think, so that the reader's thoughts are diverted from the reading to the actual writing of the book. What inspires the author to write? What does he plan to say? How does he accomplish this? are questions biriam seeks to answer. The first little hint is given when Job Greville, man-about-town, suggests that Niriam write her confessions.

Have you ever thought of committing your thouchts to paper? 'There's a book called Confessions of a iloman. It had a great sale and its composition occupied the authoress for only six weeks. You could write in your holidays $(I, 268)$.

A book presumably should contain and demand more than this. Miriam agrees that a book from the feminine point of view might be a good idea; so little has been done in that field, though Nieredith with his deep understanding of women seems to have explored the female characters more deeply than most $(I, 269)$.

l'he idea of actually writing a book receives added stimulus when Miriain renews acquaintances with her school friend Alma, and meets Alma's husband, author-critic Hypo Wilson. At Alma's clever literary people gather, trying to say things well, probably all of them writers, and talk about books is the usual procedure on Saturday afternoons. Emphasizing the increasing necessity of breaking away from 
the old forms of writing and carving a new approach to life, Hypo predicts the kind of book still waiting to be written.

Do it, Gowry ... a book [. . ]a-er-book; about a lamppost. [. . T There will be books-with all that cut out-him and her--all that sort of thing. The books of the future will be clear of all that (II, 117-118).

To readers like young Niriam they would probably lack the appeal of those by Mrs. Hungerford and Ouida.

The suggestion that Miriam should write is reiterated by IIypo. Miriam agrees, rather facetiously; had not a palmist at Newlands also told her so? And Miriam has written a few things for Home Notes, though they were rejected with some alternative suggestion. "Pieces of short prose," continues

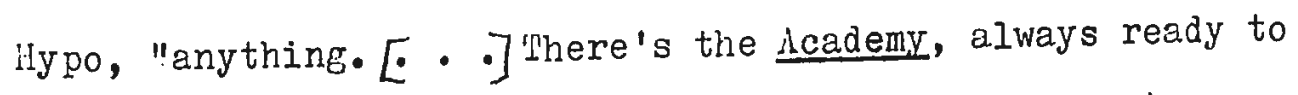
consider well written pieces of short prose (II, 129)."

Miriam is discovering the impulses, trivial though they may be, that spur men on to write; she is not surprised that books lack so much considering their motivation. liut what is writing? Miriam asks. To her it appears to be rows and rows of fine books; and men sitting in studies being important "men-of-letters," doing something cleverly and looking for approbation. If writing means merely that it will not be worth doing. To write because Mr. Wilson says so will not be right either; his reasons are wrong. Rather disturbed, Miriam takes the matter to Mag and Jan for their forthright opinion. Quite matter-of-factly Jan states that it would be foolish for Mag and Jan to attempt to write: 
anything they produced would be mediocre, and--more important-it would not sell. Neither suggests that Miriam write, but she has discovered another reason for writing, again not a good reason.

Though inwardly dejected she gaily plays a verbal game with Nag and Jan, "Barry-paroding," (imitating M. Frances Barry, the novelist): "Oh go, I said, and see the swans harping upon the roof tops in the corn." This may very well be an indirect comment upon the melodious but utterly vacuous diction of many writers.

You must not wait, nor think of words. If you are in the mood they come more quickly than you could speak or even think; $\left[\begin{array}{l}0 \\ \text { a }\end{array}\right]$ you never know what is coming and you swing about, as long as you keep the rlyythm, all over the world. Sometimes beautiful things (II, 420).

But there are authors who write books without waiting or thinking, and sometimes, too, there are the most beautiful things.

Miriam was stimulated to begin writing seriously when she helped Mr. Lahitte with his lecture on Spanish Iiterature, an occasion further used by Dorothy Richardson for an impromptu lesson on the mechanics of writing, as we have seen. In re-reading her criticism of the lecture Miriam is surprised to discover herself in her notes (yet not surpriaing, because always she finds the author is what she reads), alive, like her graver self, a revelation reflecting her character more than anything done socially, yet not 
herself, but some mysterious part of an impersonal life (III, 130-131).

Miriam is intrigued also by Hichael's suggestion that she translate a Russian story into English. Soon she is absorbed in the story, which, as she translates, begins to turn away from her towards the people waiting to read it and to share her emotions as she reads. When reading, she is acutely aware of the author; while writing, keenly conscious of the reader.

Though the translation is good, Hypo does not care for the translated stories, considering them feeble in construction and gross in sentiment. However, he advises Miriam to collect them in a book and sell them; this gives rise to her criticism of the literary field in general: it does not pay to do good work. Is ilichael conments when she discusses Hypo's suggestion with him:

You will not find cynical vulgarization of literature anywhere but in ingland and sinerica. It is indeed remarkable to the foreigner the way in this country the profession of letters has become a speculation (III, 147).

Writing is a game engaged in by the clever ones, with their ideas and style, and the determined ones making themselves writers; all are undistinguishable to the reader, and all equally enjoy the privileges and rewards of the acknowledged writer.

Miriam is entranced to find Iypo reading in the presence of Miss Prout, his house-guest, a book she is in the process

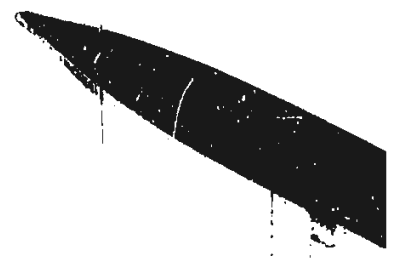


of writing. Eager to see what Hypo commends so enthusiastically, she undergoes a sudden revulsion of feeling upon discovering that Miss Prout puts actual people into her book. Miriam's mind rebels; taking people and things from life and altering them a little, is a chesp, easy way of writing a book. A writer is supposed to be a creator. H.G. Wells and Dorothy Richardson herself would both offend Hiriam in that case; they use names of real people and real places.

Meanwhile lypo gives Miriam infallible instructions for writing a review. He tells her to sniff the first page. "Glance at the conclusion. (iet your statement, three points; that'll run you through a thousand words (III, 368-369)." Mirial considers it not a very flattering picture of the authentic reviewer.

Sometime earlier, when on a visit to Oberland, Miriam picks up a thin little heavily printed continental newspaper and for the first time becomes conscious of her joy in words and phrases, the building of sentences, the movement of phrases linking part to part, all of which can be part of the beauty of a book (IV, 58).

Hypo sees journalism as the career for Miriam, but she refuses to write for the New Universe where she must take sides. Still eager to have her engage in a major literary work, Hypo suggests:

You have in your hands material for a novel, a dental novel, a human novel and, as a background, a complete period, a period of 
unprecedented expansion in all sorts of

directions. [. . . And in your outer world

you've seen an almost-ceaseless transformation,

from the beginning of the safety bicycle to

the arrival of the motor car and the aeroplane.

With the coming of flying, that period is

ending and another begins. You ought to

document your period (IV, 397).

this is advice which Dorothy Kichardson herself seems to

have put to good effect.

Iypo resunes his advice (and his revelation to us of what takes place behind the scenes): Next to clear thinking the most important of the permanent responsibilities of the writer is the business of catching himself at his best. Certain circumstances, he continues, are particularly favourable to the precipitation of felicitous phrases, meditative moments before sleep, or after a good night's rest, or the small hours of the night. l'alking, too, can be creative; that's why writers suddenly repair to their studies. Miriam's mind partially rejects this; Mrs. Boole believes one should allow deeply moving thought to pass into one's being and there work itself out (IV, 418-419).

Hypo further recommends that liriam experience life more fully before becoming a novelist. Some women can find all the experience they need in books, but Miriam should have a "green solitude," an infant, really experience life (IV, 238). Hypo's emphasis seems to suggest that a novel is the end and aim of a writer's existence; to wiriam writing even the best novel represents a dreadful enclosure.

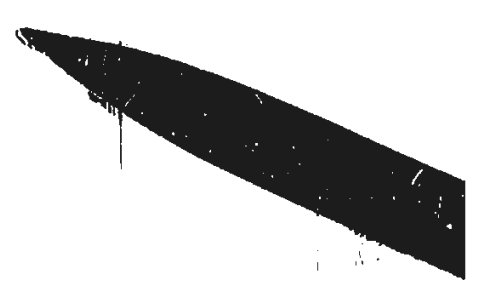


Finally, at Dimple Iill, acting upon Bob Greville's suggestion that she write her confessions, Miriam begins to write, but is soon dissatisfied, however. There is nothing in the mass of hurriedly written pages to justify the havoc-working confession. To follow Dob's misleading advice would be to leave everything out that is always there, preceding and accompanying and survivine the drama of human relationship, the reality from which penple move away as soon as they closely approach and expect each other to be all in all (IV, 525).

A review of literature would be inconplete. Miss Richardson permits Miriam to comment on this as she approaches the point of launching into the deeps of a serious writing career. Inspired by a 'middle' read and enjoyed while in Oberland, Miriam has written several successful articles, so successful, in fact, that her editor, rather ironically it would seem, advises her to discontinue writing niddles; they take too much thought. Isn't there a demand for good writing in England, Miriam wonders, or has it become, as Michael Shatov believes, 'a base trade?' liut $\mathrm{Mr}$. Godge hasn't finished. "If you describe people as well as you describe scenes, you should be able to write a novel," his letter goes on. But it is this stopping by the author to describe people that spoils so many novels, liiriain protests (IV, 613-614). Niss Richardson avoided this in pilgrimage. 
Is the writing of a novel so important? Miriam wonders. Dr. Stenhouse seems to consider it so, expressing wonder over the general love of novels and neglect of history (IV, 6Il). The explanation is given by ('watkin, a Cambridge professor during Hir. Stenhouse's time. The novelist has an advantage over the historian because he has the freedom to isolate and illuminate the interplay of human passions.

The actual writing is the thing, liririam decides. Out of, or in spite of, the welter of misdirected advice, she has found her own approach to writing.

While I write, everything vanishes but what I contemplate. The whole of what is called 'the past' is with me, seen anew, vividly. [. .] the past does not stand "being still," it móves, growing with one's rrowth. Contemplation is adventure into discovery; reality, what is called 'creation', imaginative transformation, fantasy, invention, is only based upon reality $\left[\right.$. $\left._{0} \cdot-\right]$ Fully to recognize one must be alone. Away in the farthest reaches of one with others, provided one can richly be, even have no claims (IV, 657).

Having expressed herself freely on the ills of the literary world, and having brought Miriam to the point of writing the pilgrimage that she-ligiss lichardson--has completed, Miss iichardson leaves Miriem, pen in hand, deep in those 'farthest reaches.' Dut as we move away we hear one last murmur, Novels are irrelevent.' Irrelevant to what? To something fundamental that applies to the whole mass of what ricliael Shatov calls novelistic writing--the still elusive, hidden Sometring: 


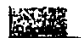

CHAP'LLR FIVE

THE FARKING-OFP PLACE

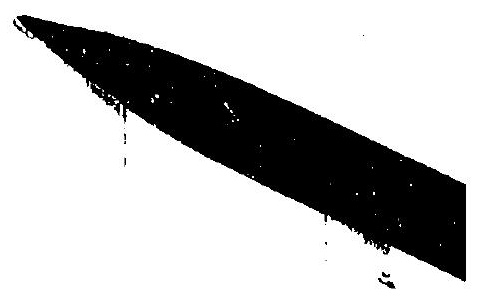


Ihus Dorothy Richardson has broucht ifiniam to the end of one phase of her pilgrimage only to have her embark upon another, that of the creative artist. If the autobioeraphical element is present, and evidence given seems to corroborate this, then Wiriam has embarked upon a literary career which will closely parallel that of Dorotly kichardson. whe ilas been patterned after Dorothy Richardson in the early stages of submitting 'middles' and reviews to current magazines; it follows therefore that her next step will be another Pilgrimage into which she will put all that she earlier deplored as having been left out. She may even draw on those reviews for material for her novel, as Dorothy Richardson undoubtedly did.

In discussing the novel with lichael Shatov, Miriem has been led to say that a novel--as distinct from other corms of writing--should not be a masterly copy of just one thing, for the reader may miss it, or may be attracted to some other aspect of the book, and would condemn himself as being ignorant for having missed it. Dorothy lichardson seems to have forestalled this contingency by including in Pilgrimage "masterly copies" of many things, though not all of equal importance.

In fact, Dorothy Richardson has lollowed the directions

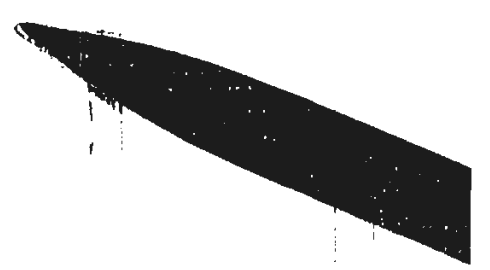

$$
-130-
$$


of Miriam's literary advisors. As Bob Greville suggested she has written a confession of her life, though she has, as Caesar Blake points out, used this confession as a means of purification, a major step toward mystic enlightenment. Acting upon Hypo Wilson's recommendations, she has documented her period, giving an intimate picture of the transition from the slow leisurely arm chair and horse-drawn tram existence to the dawning of the era of the horseless carriage, the train and the plane, of the typewriter and the new-fangled fountain pen. With reference to the latter Dorothy Kichardson felt that best results would be attained by a quill gliding gracefully across the page (III, 370). In Amabel she has orawn a vivid picture of the struggle for the emancipation of women, for their right to participate in the nation's housekeeping. Before being haled into prison, Amabel with the air of a tragedienne tucks a copy of the Ring and the Book (IV, 349) into her bag, no doubt seeing herself as another Pompilia, the victim of male selfishness and injustice. Disappointingly the reach of the prison chaplain falls far below that of Caponsacchi; Browning, he regretted, was beyond his grasp (IV, 370).

Nore important still--in keeping with her theme, what is wrong with the novel?--Dorothy Richardson has written a mamnoth review, as llypo kept insisting that she should, though with more than "a sniff" at the rirst page. Dorothy Richardson's review, as I have attempted to show, runs 
throughout Pilgrimage forming a main thread of the book. Through this 'review' we are pernitted to trace Miriam's mental development as she worries and frets the meaning from a book; we are given a glimpse of the crreatnesses and the weaknesses of the books discussed and more than a hint of their pertinence to the age in which Miriam lives; and from their attitude toward books we are permitted to make our own assessment of the people with whom Miriam associates, and the class to which they belong. "the books they read, and why they choose them, their arguments over then contribute to the general picture. For Miriam is the norm, against whom Dorothy Richardson pits the other readers, using her as a critic not only of the books but of the readers as well. Dorothy Richardson has followed her own lead in presenting a novel from a feminine point-of-view. In attempting to remedy a masculine over-emphasis on plot-seeking moderation, like the Greeks of old--she has been carried almost unexpectedly by her own efforts into a technique that has taken command of the book. She has been obliged to remove the intrusive author from the scene and permit the consciousness of liliriam to take control. The 'flow' of Miriam's consciousness is conveyed to the reader at three levels. First, there is interior monologue, when the mind of the character seems to be functioning at near-speech level, the area of consciousness being achieved by lack of logical coherence, words and phrases being used in the order 
in which they occur, while Miriam expresses awareness in the first person. Ihen there is internal analysis, when the author summarizes in simple diction the impressions of the character. Finally, there are sensory impressions, the farthest from speech formation, representing pure sensations of images by the passive mind. l'here is a dead monotony, however, to such close association with the consciousness of a single character; the reader needs the refreshment occasionally of sitting side by side ${ }^{2}$ with the central character and looking out upon the others in Miriam's world from a fresh point-of-view.

Dorothy lichardson also dispenses with overt presentation of plot. This does not mean that pilgrimage lacks plot. Just as the impressionist Painter Manet ${ }^{3}$ turned the traditional method of painting upside down, so Dorothy lichardson has up-ended the novel, giving at first level the emotional and intellectual values usually sought at a deeper level. Because Dorothy Richardson has inverted the novel, the slower process of analysis, now attempted at first meeting, gives rise to accusations of obscurity and dullness, but an entirely new concept is being presented. The plot, still there, must be pried out from under liriam's sensitive responses to her environment. Whe najor facts of her life seem to occur between the 'chapters' and are given in retrospect. Unless the reader has been given some idea ho: to approach pilsrimase--and this could very well be a test of this thesis--

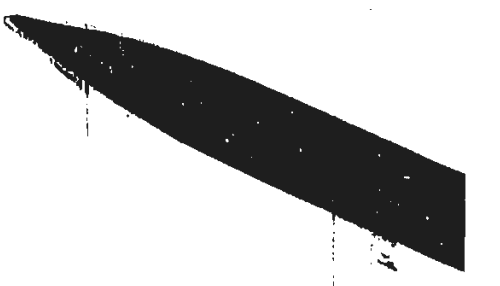


a third reading may be required to tie the threads of plot together, for we are looking, at the underside of Dorothy lichardson's "tupestry" with its knots and ends and irregular loops; it takes careful, patient concentration to retrace the design. In real life one does not always move to the next event because a previous one has occurred. Only when viewing in retrospect are we sometimes aware of the motivations of our actions; often they are so deeply hidden in the subconscious that we never meet them in the clear light of recognition.

Or, viewine it in terms of photography, ${ }^{4}$ Pilgrimage gives the negative view of what we regard as the traditional novel. The features of a plot that would be depicted in bright light to draw our attention to its peaks of conflict, causality, suspense, under Dorothy Richardson's pen have come to us in reverse, and intervening shadows have been lightened, so that the 'major events' in Pilorimage come between the volumes, or in retrospect.

Though the facts may lose their chronological significance when buffetted by the associations, memories and sensations of iiriam, careful scrutiny shows that they do follow one another in definite, logical order, trigtered by the financial fiasco of lliriam's father. 'there is also a more subtle 'interior' plot traceable through pilgrimage, every sensation, impression, memory followiug a cause-effect pattern. Not until the inclusion of March Moonlight in the Dent

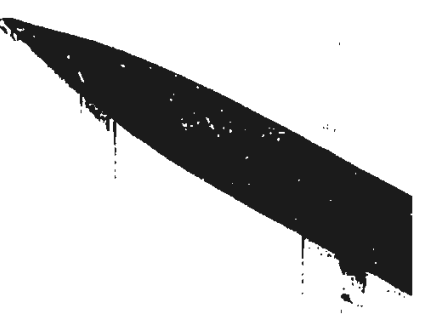


edition (1967) of Pilgrimage could one say that Pilgrimage had a semblance of a beginning, a middle and an end, though Dorothy zichardson herself does not believe in raising a deliberate curtain or in dropping one. Pilgrimage begins in medias res after her father's financial fall; it opens with liiriam's quest, back-ground material gradually being supplied through flashback or reminiscence; the middle is Miriam's journey through life via books and music and people; the end leaves Miriam in the act of writing a novel--not a full stop but pausing, giving the impression of life going on and on.

Pilgrimage possesses unity of character--Miriam being the central consistent figure. Chronological time moves. steadily through the book from ririam's seventeenth year to her fortieth, but it is looped (Dorothy Richardson's word) and twined around by psychological time as Miriam's consciousness moves outside time and space. It derives some measure of coherence from Dorothy Richardson's use of music and books. Apparently haphazardly presented, they yet have significance, each book or musical score being an interpretative means of transition from one episode to another. Through Pilgrimage runs a unified thread of people and books, separable into two individual strands: liichrel, the student, the reader and Hypo, the critic, the writer. These are the cords that bind together Dorothy Richardson's 'review' in Pilgrimare, and as liriam moves physically from

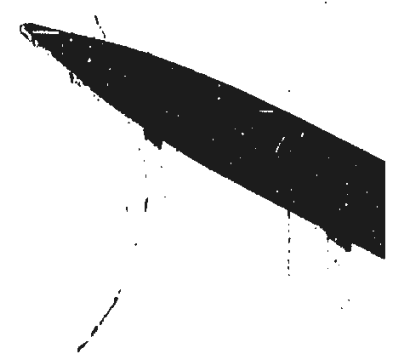


Michael to Hypo, so she moves from the role of reader to that of writer.

Critics have been highly vocative in acclaining what Pilgrimage is not, finding it perhaps more difficult to determine what it is. Pilcrimage definitely is not a novel in the traditional sense--not a 'formula' novel. But just as the 'formula' short story with its strict adherence to plot has yielded in many areas to the 'quality' short story emphasizing character, theme, atmosphere-the psychological approach--so may pilgrimage be regarded as a quality novel, minimizing traditional features and ernphasizing the psychological. 


\section{NOMES \\ CHAPTELR ONE \\ THE LESSER IHREADS}

1 Ieon Edel, The Psychological Novel: 1900-1950,

(Lond on: Rupert Ilard-Davis, 1961), p.74.

2 May Sinclair, "The Novels of Dorothy Richardson," The Egoist, V (April, 1918), p.58.

3 John C. Fowys, Dorothy M. Richardson,

(London: Joiner and Steele, 1931), p.23.

4 Walter Allen, the Enclish Novel,

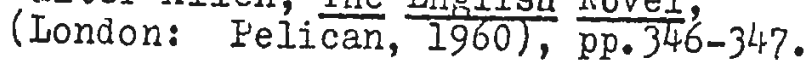

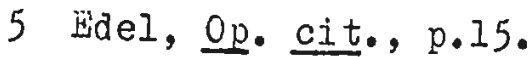

6 Caesar R. Blake, Dorothy M. Richardson,

(Ann Arbor: University of lichigan Press, 1960).

7 E.H. Niaisel, "Dorothy Mi. Richardson's Pilgrimage," Canadian Forum, XIX (June 1939), pp.89-92.

8 Gloria Glikin, Dorothy Wi. Richardson's Pilgrimage: A Critical Study, DoctoraI Thesis, 1961. Nicrofilm Copy. Original now in New York University.

9 Joseph Prescott, ed., "Data for a Spanish Fublisher," London Mercury, VI (June 1959), pp.14-19.

10 Maisel, op. cit., p.89.

II Dorotly Richardson's image of the 'little garden' may have been further deepened by her exposure to (ierman folk tales heard during her visit to Germany when she was seventeen and vividly recalled in a moment of intense emotional exhiliration--a garden that lured her away from the mundane and so mysteriously drew her; she kept trying to find it, to recapture its masic. It may also be Dorothy Iiichardson's way of showing us that all ou." experiences--"current existence"-- canl be transformed into art, even the least significant becoming part of a major work. 
11 (cont.)

In his short story "lhe Door in the Well, "il. $G$. Wells deals with a similar experience of finding an enchanted garder, beyond a green door in a white wall--an escape

into another and altogether beautiful world.

H.G. Wells, "The Door in the Vall," Story and

Structure, Laurence Perrine, ed. (New York:

Harcourt, Erace and World, Inc.), 1959, pp.272-286.

llerman Hesse's Steppenwolf also saw a little door leading into a magic theatre, a 'garden' not for everybody, but for madmen only--for the poet?

Herman Hesse, Steppenwolf, (New York: The Hodern Library), 1963, pp.34-35.

Among the classroom books at Wordsworth House, lifiam finds Browning's "Pied Piper of Hamelin," and follows the piper to a door in the mountain, opening into a wonderful land. Before Miriam and the lame boy can enter, the door closes; they merely glimpse what lay beyond.

Miriam at first sees the garden--garden upon garden--, but during the Guaker meeting at Dimple Hill, she suddenly finds herself' in the garden as a sinall field beast in a forest of grass.

12 Powys, Op. cit., pp.14-15, 41.

13 Joseph W. Beach, the Twentieth Century Novel, (New York: Appleton-Century-Crofts, 1932), p.392.

I4 Vincent Brome, "My Last Weeting With Dorothy Richardson," Lond on Niercury, VL (June 1959), p.28.

15 H.G. Wells, Experiment in Autobiosraphy, (London: Gollancz \& Cresset, 1934), p.557.

16 Harvey Eagleson, "Pedestal for Statue: The Novels of Dorothy M. Richardson," Sewance Review, XLII (1934), p.50。

17 Horace Gregory, "Dorothy Richardson Reviewed," Life and Letters Doday, XII (Merch 1959), p.37. 
CHAPTER TWO

\section{A ILASIERIY COPY OP WHNY MHINGS}

1 One could qualify this statement by noting that the modern novelist tends not only to probe more deeply into the mind of man; to transfer the reader to that vantage point from which he observes man's responses to the society in which he moves.

2 'Roscino's' was altogether different: "'Roscino,' in electric lights round the top of a little square portico, [. .] the sentry figure of the commissionaire, the passing glimpse of palm ferns standing in semi-darkness just inside the portico, [\%. - ] continental Iondon ahead of her [. . : in mingled odours of continental food and wine, rich intoxicatine odours in an air heavy and parched with the flavour of cigars, throbbing with the solid, filny, thrilling swing of music. It was a cafe!

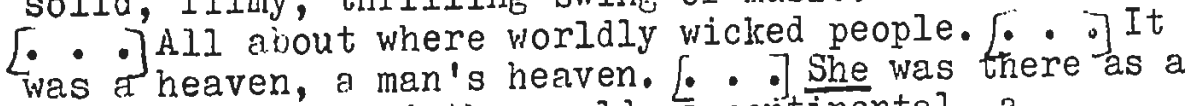
man, a free man of the world, continental, a cosmopolitan, al connoisseur of women (II, 393-394)."

"There were no marble topped tables; little square wooden legged tables; with table covers of red and blue checkered cotton; pewter flagons, foreigners, Germans, sturdy confident Germans sitting about. It was Germany." Miriam enjoyed smooth savoury broth, the bread, savoury and good through and through, the lager--the first time she had tasted beer (III, 126).

In sharp contrast her meal at the Corries was exquisite and exotic: strange, hot wine, clear, wine-flavoured soup, "the table like an island under the dowe of the low-hanging rose-shaded lamp," little dishes stuck about, sweets, curiously crusted almonds, sheeny grey-green olives; the misty beaded glass of the finger bowls, - . the four various wine glasses, red mullet, spinach, wine--all perfectly prepared, perfectly served, symbolizing the gay, sparkling luxury of the Corrie household.

This could be one of the occasions when Dorothy Richardson seems to be using symbolism in the French symbolist sense. To buy a new cake of soap, she says, is "to buy a fresh stretch of days. Its light wast, is "to buy a inutely heavy in the hand, is life, past,
present, and future, compactly welded (IV, 63)."

6 See: Chapter 1, Note 11. 
CHAMPTER THREE

SOUND AND PICIURE

1 R.A. Scott-James, "Quintessential I'eminism," London Mercury, XXXIII (November-April 1935-36), pp. $201-203$.

2 Vereker, playing the Chopin ballade at oberland, wins liiriam's friendship and approval (IV, 76-77).

Hiriam condemns Alma's rendition of Chopin, because she felt it revealed AIma's snobbish attitude towards "good music" (II, 124).

3 David Daiches, ine Novel and the Wodern World (Chicago: University of chicago Press, 1939), p.18.

4 The mountains and peaks of Switzerland exercised a constant fascination on German painters and writers; they responded violently to the endlessness and power of the Ereat crags to which they were perhaps drawn by some intellectual claustrophobia. : .

Bernard Hyers, 50 Great Artists, Bantam, New York, $1965,0.245$.

5 Michael may have been the fictional counterpart of S.S. Kosteliansky, Dorothy Richardson's friend, to whom Clear Horizon is dedicated.

6 In Hemingway's The old Man and The Sea, the right hand was strong and dependable, the left hand weak, a traitor!

7 Gloria Glikin regards Miriam's hands as being masculine, the strength on which she leans in her pilgrimage through life. At the time of her mother's death, she was so lost to the physical around her that she could not feel her hands. Ivumerous references are made to Iliriam's hands throughout pilgrimage. 


\section{CHAPTER FOUR}

\section{PROM READER TO WRITER}

1 M.E. Abrams, The Mirror and the Lamp, (New York: W. W. Horton \&: Company, 1958), p.6.

2 "ihe inatomy of Melancholy, What it is. With all the Kindes, Causes, Symptous, Prognostickes, and Several Cures of it. In three Maine Partitions and their severall Sections, Hembers and Subsections. Philosophically, liedicinally, itistorically, opened and Cut-Up. By Democritus Junior." (Everyman Edition).

3 It is interesting to note that Dorothy Richardson poses both Hypo Wilson and Michael Shatov in armchairs.

4 Indicative too of the gulf between life and the artist's comprehension of it is Yeats, across the alley f'rom Firian, blindly unaware of the rampant multitudes, his only concern his poetry and the green-robed woman, while "fifty yards away the toilers reged (III, 502)."

5 The reference to a new work of art serves also to identify the period Dorothy Richardson is reviewing.

6 And if we are to infer that Hypo Wilson is a fictional H.G. Wells, this may be construed as a criticism of the latter, too.

7 Tacts have been verified in Encyclopaedia Britannica (1958).

8 Hiriam's attitude is a good reflection of the current author-centred approach to a literary work in the late Nineteenth Century as exemplified by Sainte Beuve, whose "most critical insight and most radical method $[.:$ ] lay in the depth of his devotion to the personality of the author behind the work" (Wimsatt \& Jrooks, Iiterary Criticism, N.Y., 1957, p.535).

9 A heresey that Max Beerbohm attacks in "The Crime," (first published in And Even Now, Iondon: Heinemann, $1920)$.

10 Robert Ilumphrey, Stream of Consciousness in the Hodern Novel. Los Angeles: U. of California Press, 1954.

11 Dorothy Miller Richardson, "About Punctuation," New

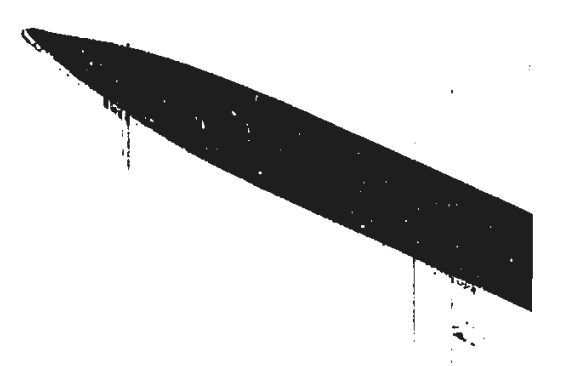
Adelphi, I $(1923-24)$, pp.990-996. 
12 Brome, Op. cit., p.30。

13 E.M. M:aisel, Op. cit. pp.89-92.

14 Pilmrimage, I, 329.

$15 \ldots, I, 438$.

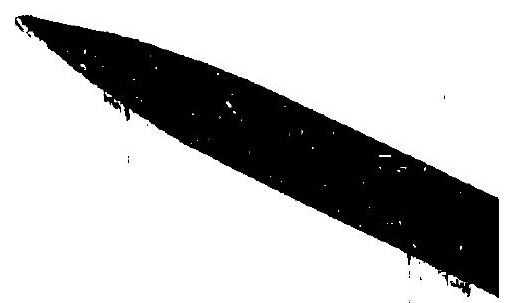


CHAPTER PIVE

THE MARKIIG-OTT PLACT

1 Jorothy Richardson devotes a chapter to Miriam's thoughts on writing a review, part of which is quoted below:

The whole process is strange. Strange and secret, always the same, always a mystery and an absence from which one returns to find life a little further on.

When the new volume arrives in its parcel, one has to endure the pang of farewell to current life that comes at the moment of going away on a visit. Everything in one's surroundings becomes attractive and precious. In their midst, threatening like a packet of explosive, lies the new book. The next moment, everything is obliterated by the stream of suggestions flowing from the read title, bringing the desire immediately to note down the various possible methods of approach busily competing for choice. To open the book is to begin life anew, with eternity in hand. But very soon, perhaps with its opening phrase, invariably during the course of the first half-page, one is aware of the author, self-described in his turns of phrase and his use of epithet and metaphor, and, for a while, oblivious of the underlying meaning in the interest of tracing the portrait, and therefore reluctant to read carefully and to write about the substance of the book rather than to paint a portrait of the autror and leave his produce to be inferred. Presently there comes a weary sense of the mass of prose extending beyond this openins display, and the turning of leaves and reading of passages here and there; the appearance of alien elements, of quotations and rleanings of facts; at last the rising of a crowd of problems, at the centre of which stands the spectre of one's own ignorance. Nothing to hold to but a half-accepted doctrine: that the reviewed should treat a book as a universe, crediting each author with a certain uniqueness and originality rather than seeking, or devising, relationships and derivations.

Lhen the careful reading from beginning to end, sometimes forgetfulness of one's enterprise in the interest of the text, and sometimes increase of panic to the point of deciding to return the book, and, nearly always, whether one feels capable or disqualified, reluctance to spend any more time on 


\section{1 (Cont.)}

it, to sacrifice an indefinite portion of one's brief leisure shut up and turned away from life.

And then the strangest of the experiences--the way, if one feels sure of one's opinion, one meets, in the interval between reading and writing, a clear and convincing expression of an alternative point of view, so that when one comes to write one nust either include it and indicate its limitations, which are not always obvious, or leave it silently presiding, undisposed of. Just as strange is the way one meets, after enduring days of being tormented by some special difficulty, in a conversation, or in a book or newspaper, something that clears it up, just in time. Ind, if there is no special afficulty, but only uncertainty as to method, keeping one uneasy when one is alone, and absent-minded when with others, one wakes one morning seeing exactly what to do and with phrases, ready-made for the turning-points of the argument, saying themselves in one's mind; again, just in time.

And yet, each time, one passes through the same miseries, forgetting.

2 A fetish of Dorotly Richardson. She and her husband and Alan Odle, always sat in chairs placed side by side. She did not believe that husband and wife should spend a life time facing each other.

3 Artists in the past worked from a dark undercoating to a series of highlichts; Manet however reversed the process, beginning with a licht under layer and adding half dark, and dark tones with the result that light was reflected by the underpainting.

4 Hypo, the name of one of the characters is also the name of a chemical used in photocraphy--sodium hyposulphate. 


\section{BIBLIOGRAPHY}

1. This section lists the first publication of the "chapters" of pilgrimage.

Pointed Roofs. London: Duckworth, 1915.

Backwater. Iondon: Duckworth, 1916.

Honeycomb. Iondon: Duckworth, 1917.

The Tunnel. London: Juckworth, 1917 (liebruary).

Interim. London: Duckworth, 1919 (December).

Deadlock. London: Duckworth, 1921.

Revolving Lights. London: Duckworth, 1923.

The Trap. London: Duckworth, 1925.

Oberland. London: Duckworth, 1927.

Dawn's Left Iand. Iondon: Duckworth, 1931.

Clear Horizon. London: Dent ic Cresset, 1935.

March Moonlight. Published in "Work in Progress in

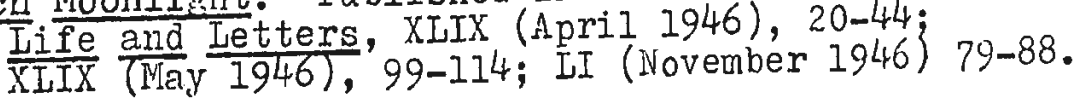

2. Collected iditions. (Ihese were reprinted by Alfred $A$. Knopf).

Pilgrimage. 4 vols. Iondon: Dent i Uresset, 1938.

Pilgrimage. 4 vols. London: Dent, 1967.

3. Other works by Dorothy Miller liichardson.

(a) Keviews

"Portrait of an ivangelist," New Adelphi, I

(Yarch 1928), 270-271.

$$
-145-
$$


"Mr. Clive Bell's Proust," New Adelphi, II (December 1928 - February 1929), $\overline{160}-\overline{162}$.

"The Return of William Wordsworth," Adelphi (Supplement), new series, I (December 1930), XVI-XIX.

"Man Never Is ...," Adelphi, new series, 1 (March 1931), 521-522.

"Adventures for Readers," Iife and Letters Ioday, XXII (July 1939) 45-52.

(b) Essays

"About Punctuation," Adelphi, 1 (April 1924), 990-996.

"The Status of IIlustrative Art," Adelphi, 111 (June 1925), 54-57.

"Leadership in Harriage," New Adelphi, II (August 1929), $345-348$.

"Yeats of Bloomsbury," Iife and Letters loday, XXI ( $\Lambda$ pril 1939), 60-66.

- "Novels," Iife and Letters, LVI (March.1948), 188-192.

(c) Short Stories

"Visitor," Iife and Letters, XIVI (September 1945), $167-172$.

"Visit," Life and Letters, XIVI (September 1945), 173-181. 
4. Selected Critical and Reference Works.

Allen, Walter. The Inglish lovel. New York: Dutton, 1955. - The Modern Novel. New York: Dutton, 1964.

Beach, Joseph W. The Twentieth Century Hovel. New York: Appleton-Century-Crofts, 1932 .

Bentley, Phyllis. Some Observations on the Art of Narrative. Iondon: Home and Van Thal, 1946.

Blake, Caesar Robert. Dorothy Richardson. University of Michigan Press, 1960.

Booth, Wayne C. The Rhetoric of Hiction. Chicago: The University of Chicago Press, 1965.

Brittain, Vera. Lady into Woman. irew York: the Macmilian Co., 1953.

Daiches, David. The Novel and the liodern World. Chicago: University of Chicago Press, 1939.

Edel, Leon. The Psychological Novel: 1900-1950. New York: Jippincott, 1955.

Edgar, Pelham. The Art of the Novel. New York: Nacmilian, $1 \overline{933}$.

Forster, E. IH. Aspects of the Novel. New York: Harcourt and Brace, 1927.

Fraser, G.S. The Hodern Writer and His World. Iondon: Verschoyle, 1953.

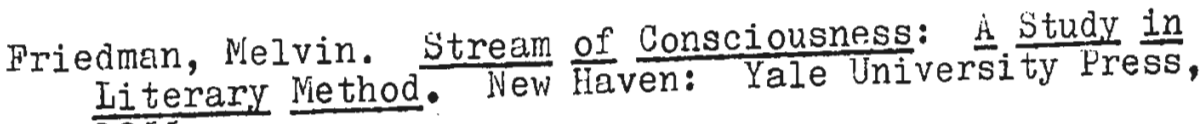
1955.

Glikin, Gloria. Dorothy Richardson's Pilurimage: Critical study. New York University, 1961, University Microfilms, 64-9659.

Grabo, C.H. Technique of the Novel. New York: Gordian Press, 1964. Ilumphrey, Robert. Stream of
Novel. University of California Press,
Cons

Karl, irederick R. and Magalaner, Marvin. A Reader's Guide to Twentieth-Century Engligh Novels. liew York: Noonday Fress, 1965. 
Lubbock, Fercy. the Craft of Fiction. New York: Peter Smith, 1947.

Nansfield, Katherine. Novels and Novelists. id.

J. Viddleton Furry. Lond on: Constable, 1930.

Nendilow, A.A. Nime and the Novel. London: Peter Nevill, 1952.

Millett, Fred B. Contemporary British Iiterature. New York: Harcourt and Brace, 1948.

Irixir, Edwin. The Structure of the Novel. London: Hogarth, 1928.

Murry, J. Hiddleton. The Froblems of Style. Oxford: 1949.

Powys, John C. Dorothy M. Kichardson. London: Joiner and Steele, 1931.

Schorer, Mark, ed. Hodern British Fiction. New York: Oxiord, 1964.

Scott-James, R.A. Pifty Years of English Literature: 1900-1950. London: Longmans, Green and Co., 1951.

Swinnerton, Frank. The Georgian scene. New York: I'arrar and linehart, $19 \overline{34}$.

Wagenknect, Ldward. Cavalcade of the English Novel

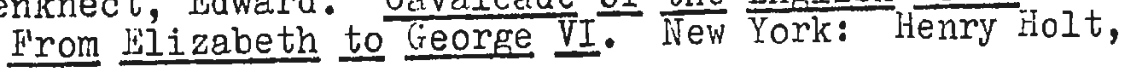
1943.

Wells, H. G. Lxperiment in Autobiography. 2 Vols. London: Gollancz \& Cresset, 1934.

Wilson, Edmund. Axel's Castle. New York: Scribner, 1931.

Bowling, I. i. "What is Stream of Consciousness Technique?" Publications of the Modern Language Association, LXV (1950), $337-345$.

Brome, Vincent. "Ny Last lieeting with Dorothy Richardson," London Magazine, VI (June 1949), pp.26-32.

Bourne, Kardolph. "An Inagist Novel," Dial, LXIC-LXXV (1918).

"Cagey Subconsciousness." Anon. review of PiIgrimage,

Ilime, XXXII (December 5, 1938), p.70. 
"Deadlock," Anon. review, Spectator, CXXVI (1921), p.403.

Deutsch, Babette. "Treedom and the Grace of God," Dial, IXVII (November 15, 1919), pp. 441-442.

Lagleson, Harvey. "Yedestal for Statue: The Novels of Dorothy M. Richardson," Sewanee Review,

XIII (1934), pp. 42-53。

"Fiction of To-day." Anon review of Backwater, the Saturday Review (Iondon), CXXII (1916) p.138.

Glikin, Gloria. "Dorothy M. Richardson: the Personal Pilgrimage," PMIA, IXXVIII (December 1963), pp.586-600.

Gregory, Horace. "Dorothy Richardson Reviewed." Iife and Letters To-day, XXI (March, 1939), pp.36-45.

Hunt, Una. Review of Deadlock, New Republic, XXIX (1922), pp.313-314.

Hyde, Lawrence. "The Work of Dorothy Richardson," Adelphi, II (1924), pp.508-517.

Maisel, E.M. "Dorothy M. Richardson's Pilgrimage," Canadian Forum, XIX (June 1939), pp.89-92。

"Miss Dorothy Richardson," Obituary, Lond on Times, June 18, 1957, p.13.

"New Novels. Honeycomb," Times Literary Supplement, XVI (October 16, 1917), p.506.

"New Novels. Interim." Anon. review, Times Literary Supplement, XVIII (December 18, 1919), p.766.

P.I. "Books and Ihings," New Republic, XXVI (1921), p. 267 .

"Pilgrimage." Mnon. review, Nation, OIX (1919), pp.720-721. Prescott, Joseph. "Richardson, Dorothy lilier,"
incyclopaedia Britannica (1958), XIi, p.289.

, ed. "Date for a S̈panisi Publisher," London IV arazine, VI (June, 1959), pp.14-19.

"Proust, Joyce, and Wiss Richardson," the spectator, CXXX (1923), pp.1084-85. 
Rosenfeld, Paul. "Ihe Inner Iife," Saturday Review of Literature, XIX (December 10, 1938), p.6.

Rourke, Constance. "Dorothy M. kichardson," the iNew Kepublic, XX (liovember 26, 1919), pt. II, $\frac{1}{\mathrm{p} .14}$

Scott, Evelyn. "A Contemporary of the Future," Dial, IXIX (1920), pp.353-367.

Scott-James, K.A. "Quintessential Feminism," London Mercury, XXXIII (December, 1935), pp.201-03.

Sinclair, Fiay. "Ihe Novels of Dorothy litichardson," igoist, V (April, 1918), pp.57-59。

Trickett, ilachel, "The Living Dead--V: Dorothy

Richardson," London liagazine, VI (June 1959), pp.20-25.

"The Tunnel." Anon. review, Spectator, CXXII (1919), pp.330-331.

"The Iunnel." Aron. review, Times Iiterary Supplenent,

XVIII (ievruary 13,1919$), \mathrm{p} .81$. 



